
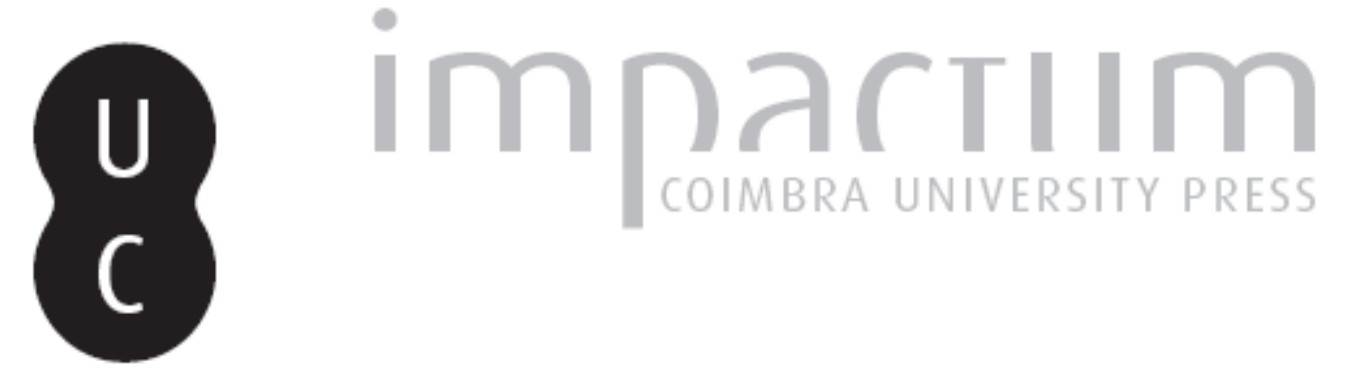

\title{
Antero de Quental: elementos para uma bibliografia
}

Autor(es): $\quad$ Azenha, Maria do Rosário

Publicado por: Imprensa da Universidade de Coimbra

URL persistente:

URl:http://hdl.handle.net/10316.2/43755

DOI:

DOI:https://doi.org/10.14195/2183-8925_13_18

Accessed : $\quad$ 26-Apr-2023 03:46:13

A navegação consulta e descarregamento dos títulos inseridos nas Bibliotecas Digitais UC Digitalis, UC Pombalina e UC Impactum, pressupõem a aceitação plena e sem reservas dos Termos e Condições de Uso destas Bibliotecas Digitais, disponíveis em https://digitalis.uc.pt/pt-pt/termos.

Conforme exposto nos referidos Termos e Condições de Uso, o descarregamento de títulos de acesso restrito requer uma licença válida de autorização devendo o utilizador aceder ao(s) documento(s) a partir de um endereço de IP da instituição detentora da supramencionada licença.

Ao utilizador é apenas permitido o descarregamento para uso pessoal, pelo que o emprego do(s) título(s) descarregado(s) para outro fim, designadamente comercial, carece de autorização do respetivo autor ou editor da obra.

Na medida em que todas as obras da UC Digitalis se encontram protegidas pelo Código do Direito de Autor e Direitos Conexos e demais legislação aplicável, toda a cópia, parcial ou total, deste documento, nos casos em que é legalmente admitida, deverá conter ou fazer-se acompanhar por este aviso.

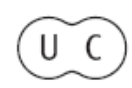


REVISTA DE HISTÓRIA DAS IDEIAS 13

\section{Antero de Quental}

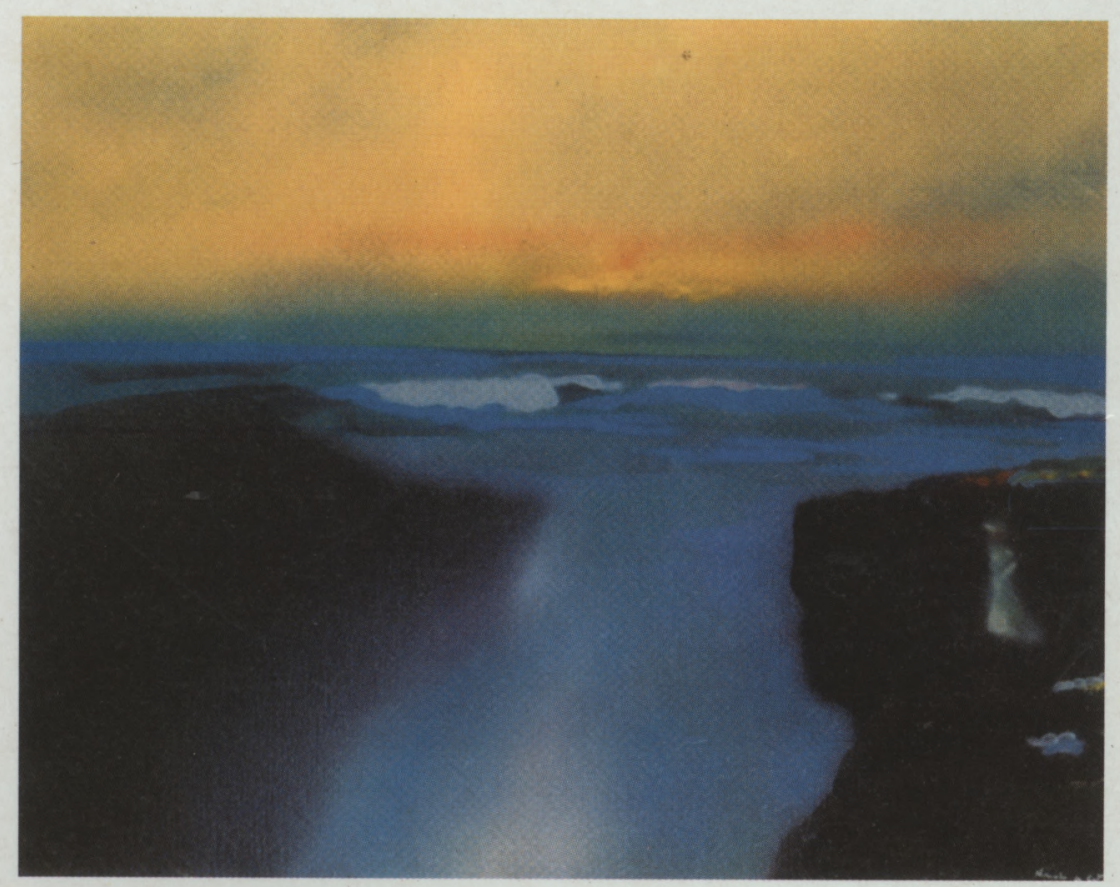

INSTITUTO DE HISTÓRIA E TEORIA DAS IDEIAS FACULDADE DE LETRAS

COIMBRA 1991 


\section{ANTERO DE QUENTAL: ELEMENTOS PARA UMA BIBLIOGRAFIA}

Solicitou-me o Prof. Fernando Catroga, coordenador deste número da Revista de História das Ideias dedicado a Antero de Quental, a elaboração de uma bibliografia. Tentei, assim, fazer uma bibliografia o mais completa possível de obras e artigos de e sobre Antero. Nela incluo todas as publicações encontradas, independentemente do seu valor científico. Sempre que possível completei as referências. No entanto, em certos casos, por não ter encontrado os espécimes nas bibliotecas, figuram sem alguns dados, tais como o local de edição, a editora, ou o número de páginas.

Cumpre-me agradecer à $\mathrm{Dr}^{2}$ Ana Maria Almeida Martins o apoio que me concedeu neste trabalho.

Por terem sido detectadas algumas (inevitáveis) lacunas na presente bibliografia, e devido ao facto de, entre a sua elaboração e o fecho do ciclo comemorativo do centenário da morte de Antero e do aniversário dos cento e cinquenta anos do seu nascimento, terem saído alguns estudos que merecem registo, esta listagem será continuada no próximo volume da Revista.

* Faculdade de Letras da Universidade de Coimbra. 
Antero de Quental

\section{OBRAS DE ANTERO DE QUENTAL}

\section{POESIA:}

Algumas poesias suas pouco conhecidas (Não entradas em nenhum dos volumes das suas obras, vindas à luz). Introd. e ed. de Rodrigo Veloso. Barcelos, Tip. do Aurora do Cávado, 1894. 68 p.

Alguns sonetos de Anthero de Quental. Trad. de S.R. Koehler. Ponta Delgada, s.n., 1918. 15 p.

Antologia poética de Antero de Quental. Selec. e notas de Ruy Galvão de Carvalho. Angra do Heroísmo, Secretaria Regional de Educação e Cultura, 1983. 324 p.

Beatrice. Coimbra, Imprensa da Universidade, 1863.39 p.

Cadencias vagas. Versos colligidos por Joaquim de Araújo. Lisboa, Typ. da Academia Real das Sciencias, 1892. VIII+72 p.

Esparsos e traduç̧ões, tradução alemã, espanhola e italiana. Porto, Companhia Portugueza Editora, 1918.96 p.

As fadas. Lisboa, Contexto e Imagem, 1984. 18 p. il.

Fiat Lux. Coimbra, Imprensa da Universidade, 1863. 16 p.

"Hino da Manhã" e outras poesias do mesmo ciclo. Lisboa, Livros Horizonte, 1989. 83 p.

Os mais belos sonetos de Antero. Sel. por José Régio. Lisboa, Artis, 1966.

Odes Modernas. $1^{\text {a }}$ ed. Coimbra, Imprensa da Universidade, 1865. $160 \mathrm{p}$.

Odes Modernas. Contendo várias composições inéditas. $2^{\mathrm{a}}$ ed.. Porto, Livraria Internacional de Ernesto Chardron, 1875. 186 p.

Odes modernas. $3^{\mathrm{a}}$ ed. Contendo varias composições inéditas. Porto, Livraria Chardron, $1898.190 \mathrm{p}$.

Odes Modernas. Nova edição. Coimbra, Imprensa da Universidade, 1924. $214 \mathrm{p}$.

Odes Modernas. $5^{\mathbf{a}}$ ed. Vol. II das Obras de Antero de Quental. Org., pref. e notas de António Sérgio. Lisboa, Ed. Couto Martins, 1943. $238 \mathrm{p}$.

Odes Modernas. Ed., org. e notas de António Sérgio. Lisboa, Couto Martins, 1952. 207 p. 
Odes Modernas. Org., pref. e notas de António Sérgio. Lisboa, Companhia Nacional Editora, 1952. 207 p.

Odes Modernas. Pref. de Nuno Júdice. $2^{\mathrm{a}}$ ed.. Lisboa, Ulmeiro, 1983. $212 \mathrm{p}$.

Poesia completa. Pref. de Nuno Júdice. Lisboa, Círculo de Leitores, 1991. 2 vols.

Poesias de Antero de Quental. Apres. crítica, selec., notas e sugestões para análise literária de Maria Madalena Gonçalves. Lisboa, Seara Nova, 1981. p. 157.

Primaveras romanticas. (Versos dos vinte annos)(1861-1864). Porto, Imprensa Portugueza Editora, 1872. 202 p. il.

Primaveras românticas. Versos dos vinte anos. (1861-1864). $2^{\mathrm{a}}$ ed.. Coimbra, Imprensa da Universidade, 1922. VII+194 p.

Primaveras romanticas. Versos dos vinte anos (1861-1864). $3^{\mathrm{a}}$ ed.. Coimbra, Imprensa da Universidade, $1926.194 \mathrm{p}$.

Primaveras românticas. $4^{\mathrm{a}} \mathrm{ed}$. Vol. III. de Obras de Antero de Quental. Ed. org., pref. e notas de António Sérgio. Lisboa, Couto Martins, 1943. $256 \mathrm{p}$.

Primaveras românticas. Porto, Lello \& Irmão, 1984. 232 p.

Primaveras românticas: Versos dos vinte anos (1861-1864). Pref. de Nuno Júdice. Lisboa, Ulmeiro, 1984. 169 p.

Raios de extincta luz. Poesias ineditas (1839-1863) com outras pela primeira vez colligidas. Publicadas e precedidas de um escorso biographico por Theophilo Braga. Lisboa, M. Gomes, LivreiroEditor, 1892. XLVIII+258 p.

Raios de extinta luz, $2^{\mathrm{a}}$ ed. Pref. Joaquim de Carvalho. Lisboa, Couto Martins, 1945. $168 \mathrm{p}$.

Raios de extinta luz e outras poesias. Pref. de António Salgado Júnior e notas de José Bruno Carreiro. Lisboa, Couto Martins, 1948. XLII+269 p.

Raios de extinta luz. Pref. Joaquim de Carvalho. Porto, Livraria Chardron de Lello \& Irmão, 1987. 168 p.

Serenata. Porto, Typographia Occidental, 1894. 4 p. in.

Sonetos de Antero. Editor Stenio (Pseud. de Alberto Teles). Coimbra, Imprensa Litteraria, 1861. XII+23 p.

Sonetos. Porto, Imprensa Portugueza, 1881. 32+4 p.

Os Sonetos completos de Anthero de Quental. Publ. por J. P. Oliveira Martins. Porto, Liv. Portuense de Lopes \& C $C^{a}$ Editores, 1886. 
$(48+126) \mathrm{p}$.

Os Sonetos completos de Anthero de Quental. Publ. por J.P. Oliveira Martins. $2^{a}$ ed. augmentada com um appendice contendo traduç̧ões em allemão, francês, italiano e espanhol. Porto, Livraria Portuense Lopes \& C", Editores, 1890. 184+VI p.

Os Sonetos completos de Antero de Quental. $3^{\mathrm{a}}$ ed.. Porto, Companhia Portugueza Editora, 1918. XXXI+160 p.

Os Sonetos completos de Antero de Quental. Porto, Companhia Portuguesa Editora, 1919. XXXI+160 p.

Os Sonetos completos de Anthero de Quental. Pref. por J.P. Oliveira Martins. Nova edição. Coimbra, Imprensa da Universidade, 1922. $46+126 \mathrm{p}$.

Os Sonetos de Anthero de Quental. Nova edição. Pref. de J. P. Oliveira Martins. Coimbra, Imprensa da Universidade, 1924. 46+125 p.

Os Sonetos completos de Antero de Quental. Nova edição. Coimbra, Imprensa da Universidade, $1933.46+125 \mathrm{p}$.

Sonetos. Vol. I de Obras de Antero de Quental. Ed., org., pref. e notas de António Sérgio. Lisboa, Couto Martins, 1943. 343 p.

Os Sonetos completos de Antero de Quental. Pref. de J. P. Oliveira Martins. Lisboa, Couto Martins, 1945.

Sonetos de Antero de Quental. Introd., selec. e notas de Emanuel Paulo Ramos. Para os alunos do $7^{\circ}$ ano do Curso Complementar de Letras. Coimbra, Quadrante, 1950. $128 \mathrm{p}$.

Sonetos. Org., pref. e notas de António Sérgio. Famalicão, 1955. $351 \mathrm{p}$.

Sonetos. Org., pref. e notas de António Sérgio. Lisboa, Couto Martins, 1956. $351 \mathrm{p}$.

Os Sonetos completos de Antero de Quental. Pref. de J.P. Oliveira Martins. Nova edição. Lisboa, 1958. 171 p.

Sonetos de Antero de Quental. Introd., selec. e notas de Emanuel Paulo Ramos para os alunos dos Cursos de Letras (Liceus, Colégios e Seminários). $2^{\mathrm{a}}$ ed.. Porto, Porto Editora, 1962.108 p.

Sonetos. $1^{\text {a }}$ ed. Org., pref., e notas de António Sérgio. Lisboa, Sá da Costa, 1962. LXXXVII+287 p.

Sonetos. $2^{\mathrm{a}}$ ed. Ed., org., pref. e notas de António Sérgio. Lisboa, Sá da Costa, 1963. LXXXVII+275 p.

Sonetos. Org., pref. e notas de António Sérgio. Lisboa, Couto Martins, 1965. $351 \mathrm{p}$. 


\section{Elementos para uma bibliografia}

Sonetos. $3^{\text {a }}$ ed. Org. de António Sérgio. Lisboa, Sá da Costa, 1968. LXXXVII+287 p.

Sonetos. $4^{a}$ ed. Org. por António Sérgio. Lisboa, Sá da Costa, 1972. LXXXVII+287 p.

Sonetos. $5^{\text {a }}$ ed. Org., pref., e not. por António Sérgio. Lisboa, Sá da Costa, 1976. LXXXVII+287 p.

Sonetos. Introd., selec. e notas de Emanuel Paulo Ramos. Porto, Porto Editora, 1978. $196 \mathrm{p}$.

Sonetos. $\sigma^{a}$ ed. Org., pref. e notas de António Sérgio. Lisboa, Sá da Costa, 1979. LXXXVII+287 p.

Sonetos completos. Pref. de Oliveira Martins. Porto, Nova Crítica, 1980. $172 \mathrm{p}$.

Sonetos completos. Mem Martins, Europa-América, 1981. 170 p.

Sonetos completos. Pref. de Oliveira Martins. Porto, Lello \& Irmão, 1983. $190 \mathrm{p}$.

Sonetos. $7^{a}$ ed. Org., pref. e notas de António Sérgio. Lisboa, Sá da Costa, 1984. LXXXVII+287 p. il.

Sonetos completos. Pref. de Oliveira Martins. Porto, Anagrama,(1984). $172 \mathrm{p}$.

Sonetos. Pref. de Nuno Júdice. Lisboa, Ulmeiro, 1985. 160 p.

Sonetos. Pref. de Oliveira Martins. Lisboa, Marujo, 1986. 172+4 p.

Sonetos. Lisboa, Círculo de Leitores, 1987. 144 p.

Sonetos completos de Antero de Quental. Nova ed. Com pref. de J.P. de Oliveira Martins. Lisboa, Couto Martins, s.d.. 27+CLXXVII p. Sonetos de Antero de Quental. Coimbra, Gráfica de Coimbra, s.d.

Sonetos de Antero de Quental. Ed., e org. de Emanuel Paulo Ramos. Porto/Lisboa, Porto Editora/Empresa Literaria Fluminense, s.d.. $108 \mathrm{p}$.

Sonetos. Introd., selec. e notas de Emanuel Paulo Ramos. Para os alunos do $7^{\circ}$ ano do Curso Complementar de Letras. Coimbra, Dep. Livraria Gonçalves, s.d.. 128 p.

13 sonetos de Vila do Conde. Vila do Conde, Ed. das Celebrações do Centenário da Morte de Antero de Quental, 1991.

Uma poesia inédita de Anthero de Quental: Ao sr. Alexandre Herculano. s.l., Ilustração Portuguesa, 1907. 5 p. il.

Versos de Carlos Fradique Mendes. Recolha, pref., e notas de Pedro da Silveira. Lisboa, Edições 70, 1971.

Zara. Edição polyglota. Introd. de Joaquim de Araújo. Lisboa, Im- 
prensa Nacional, 1894. XV+89 p.

Zara. $2^{\text {a }}$ ed. polyglota. Lisboa, Imprensa Nacional, 1925.89 p.

Zara. Pref. de Joaquim de Araújo. Lisboa, Ed. Couto Martins, 1943. $78 \mathrm{p}$.

\section{PROSA:}

"Acta do duello entre Cypriano Jardim e Camillo Castello Branco", $O$ Primeiro de Janeiro, 24 Out. 1879.

Alexandre Herculano. Barcelos, Tip. do Aurora do Cávado, 1896. $14 \mathrm{p}$.

"Arte e verdade", Revista do Século, $1^{\text {a }}$ série, Lisboa. p. 39.

Arte e verdade. Barcelos, Tip. do Aurora do Cávado, 1895. 24 p.

"A Bíblia da Humanidade", O Século XIX, 91, 94, 99, 101, Penafiel, 1885.

A Bíblia da Humanidade. Barcelos, Tip. do Aurora do Cávado, 1895. $38 \mathrm{p}$.

Bom senso e bom gosto - Carta ao Excelentíssimo Senhor António Feliciano de Castilho. Coimbra, Imprensa da Universidade, 1865. 16 p.

Bom senso e bom gosto - Carta ao Excellentissimo senhor António Feliciano de Castilho. $3^{\mathrm{a}}$ ed.. Coimbra, Imprensa Litteraria, 1865. 16 p.

Carta ao Exm ${ }^{\circ}$ Sr. António José de Ávila, Marquezde Ávila, Presidente do Conselho de Ministros. (Lisboa), Tipografia do Futuro, 1871. 8 p.

"Casas nobres inglesas", Europa Pittoresca, 1, Paris, 1881. p. 31-59. Causas da decadência dos povos peninsulares nos últimos três séculos. Discurso pronunciado na noite de 27 de Maio, na Sala do Casino Lisbonense. Porto, Typographia Commercial, 1871. 48 p. Causas da decadência dos povos peninsulares. Lisboa, Ulmeiro, 1970. $63 \mathrm{p}$.

Causas da decadência dos povos peninsulares. $2^{\mathrm{a}}$ ed.. Lisboa, Ulmeiro, $1971.69 \mathrm{p}$.

Causas da decadência dos povos peninsulares. $3^{\mathrm{a}}$ ed.. Lisboa, Ulmeiro, $1979.69 \mathrm{p}$.

Causas da decadência dos povos peninsulares. $4^{\mathrm{a}}$ ed.. Lisboa, Ulmeiro, $1982.69 \mathrm{p}$. 
Causas da decadência dos povos peninsulares. $5^{\text {a }}$ ed.. Lisboa, Ulmeiro, $1987.69 \mathrm{p}$.

"O Congresso da Internacional na Haia", O Pensamento Social, 25, Lisboa, Out. 1872. (Saiu anónimo).

"Correspondência de Coimbra", O século XIX, 11, Penafiel, 6 Abr. 1864.

Considerações sobre a philosophia da história litteraria portugueza (A propósito de alguns livros recentes). Porto, Livraria Internacional de Ernesto Chardron, 1872.38 p.

Considerações sôbre a philosophia da história litterária portugueza. (A propósito de alguns livros recentes). $2^{\mathrm{a}}$ ed.. Porto, Livraria Chardron, Lello \& Irmão Editores, 1904.46 p.

Os críticos de Fausto. Carta ao Exmo. sr. José Gomes Monteiro. Porto, s.n., $1873.4 \mathrm{p}$.

Os Críticos do Fausto (Carta ao Exm ${ }^{\circ}$ Sr. J. Gomes Monteiro). Barcelos, Tip. do Aurora do Cávado, 1896. 12 p.

"Da reorganização social", Revista Ocidental, 1, Lisboa, 1875. p. 764$-766$.

Da reorganização social - Aos trabalhadores e proprietários, por João Bonança. Barcelos, Tip. do Aurora do Cávado, 1896. 20 p.

"Das Revistas de Coimbra", Grémio Alentejano, 4, Coimbra, Out. 1861.p. 1.

Das revistas de Coimbra. Barcelos, Tip. do Aurora do Cávado, $1896.16 \mathrm{p}$.

Defesa da carta encyclica de Sua Santidade Pio IX contra a opinião liberal. Considerações sobre este documento. Coimbra, Imprensa Litteraria, 1865. 32 p.

Defesa da carta encyclica de Sua Santidade Pio IX contra a opinião liberal. Considerações sobre este documento. $2^{\mathrm{a}}$ ed.. Coimbra, Imprensa Litteraria, 1865. $31 \mathrm{p}$.

"Democracia", Almanak para a Democracia Portuguesa, $1^{\circ}$ ano, Lisboa, 1870. p. 41-44. (Saiu anónimo).

A dignidade das letras e as litteraturas oficiaes. Lisboa, Typografia Universal, $1865.48 \mathrm{p}$.

"As duas democracias", O Pensamento Social, 8, Lisboa, Abr. 1872. (Saiu anónimo).

Duas palavras a propósito do folheto do sr. Teófilo Braga, mas não em resposta ao sr. Teófilo Braga nem ao seu folheto. Coimbra, 1896. 
$20 \mathrm{p}$.

A Edade Média na história da civilisação. Polemica entre Antero de Quental, J.P. Oliveira Martins e Dr. Júlio de Vilhena. Pref. e not. de Francisco d'Assis d'Oliveira Martins. Lisboa, Parc. António Maria Pereira, 1925. 193 p.

"Educação das mulheres", Preludios Litterarios, 1(13), Coimbra, 1858-1859. p. 149-151.

A educação das mulheres. Barcelos, Tip. do Aurora do Cávado, 1894. $18 \mathrm{p}$.

"Esbocetos biográficos. Introdução", O Académico, 1, Coimbra, Mar. 1860. p. 25-26.

"Esbocetos biográficos. O Infante D. Henrique", $O$ Académico, 2-3, Coimbra, Abr. 1860. p. 49-52; p. 86-90.

Estatutos da Associação Protectora do Trabalho Nacional. Lisboa, Tipografia de J. C. Almeida, $1873.48 \mathrm{p}$.

"Expiação", Província, 6ª ano, Porto, 26 Jan. 1890.

Expiação. Barcelos, Tip. do Aurora do Cávado, 1897. 12 p.

"Espontaneidade", O Instituto, 13(8), Coimbra, 1866. p. 185-188.

Espontaneidade. Barcelos, Tip. do Aurora do Cávado, 1895. $30 \mathrm{p}$.

"Guerra de classes", O Pensamento Social, 4, Lisboa, Março 1872. (Saiu anónimo).

"O 'Fausto' do snr. Visconde de Castilho", Primeiro de Janeiro, 4 Jul. 1872. (Saiu anónimo).

"O futuro da música", O Instituto, 13(10), Coimbra, 1866. p. 234-240.

O futuro da Música. Barcelos, Tip. do Aurora do Cávado, 1895. $48 \mathrm{p}$.

"A Ilustração e o operário", O Cisne do Mondego, Coimbra, Out. 1860, 2 .p. 6; 3, p. 10.

"A indiferença em política", Grémio Alentejano, 26, 28, 31, Coimbra, Abr., Maio 1862. p. 1; 1; 2.

A indiferença em política. Barcelos, Tip. do Aurora do Cávado, 1896. $30 \mathrm{p}$.

$O$ Infante D. Henrique (Fragmentos). Barcelos, Tip. do Aurora do Cávado, 1893.

$O$ Infante D. Henrique. Pref. de Rodrigo Veloso. Lisboa, Imprensa Nacional, 1894. 59 p.

O Infante D. Henrique. Pref. de Rodrigo Veloso. Lisboa, M. Gomes, Editor, 1904. 59 p. 


\section{Elementos para uma bibliografia}

"A influência da mulher na civilização", Estreia Literária, $2^{\mathrm{a}}$ série, 1, 15 Nov. 1860. p. 4-6; 2, 30 Nov. 1860. p.11-12; 4, 31 Dez. 1860.p. 27-28; 11, 15 Abr. 1861, p. 82-83.

A influência da mulher na civilização. Barcelos, Tip. do Aurora do Cávado, $1896.40 \mathrm{p}$.

O Japão - Estudos e impressões de viagem, por Pedro Gastão Mesnier. Barcelos, Tip. do Aurora do Cávado, 1896. 16 p.

A João de Deus. Com duas palavras de Joaquim de Araújo. Génova, Tipografia R. Istituto Sordo-Muti, 1897. 16 p.

"Julio Michelet (Por occasião da sua morte)", Nova Alvorada, Anno 8, $n^{\circ} 6$ e 7,Vila Nova de Famalicão, Out. e Nov. 189. p. 141-143.

Júlio Michelet. Barcelos, Tip. do Aurora do Cávado, 1896. 30 p.

"Leituras Populares", Preludios Litterarios, Coimbra, 1860-1861, 2(2). p. 9-10; 2(3). p. 17-19; p. 2(4). p. 25; 2(6). p. 41-42; 2(8). p. 57-58; 2(15). p. 116;2(20). p. 153.

Leituras populares. Barcelos, Tip. do Aurora do Cávado, 1896. 66 p. Liga Patriótica do Norte. Barcelos, Tip. do Aurora do Cávado, 1896. $20 \mathrm{p}$.

Lopes de Mendonça. Barcelos, Tip. do Aurora do Cávado, 1894. 28 p. Manifesto dos estudantes da Universidade de Coimbra à opinião ilustrada do País - 1862-1863. Barcelos, Tip. do Aurora do Cávado, 1896. $24 \mathrm{p}$.

As 'Meditações poéticas' de Lamartine", $O$ Phosphoro, 1-2, 1860.

"As 'Meditações poéticas' de Lamartine". Barcelos, Tip. do Aurora do Cávado, 1894. 20 p.

"A morte de D. João I (A proposito de um poema do snr. Guerra Junqueiro)", Nova Alvorada, $4^{\circ}$ Anno, $\mathrm{n}^{\circ}$ 9, Vila Nova de Famalicão, 1 Dez. 1894 p. 178-179.

A morte de D. João. Barcelos, Tip. do Aurora do Cávado, 1896. 20 p.

"Na sentida morte do meu condiscípulo e amigo Martinho José

Raposo", Preludios Litterarios, 2 (2), Coimbra, Jan. 1860. p. 13.

Na sentida morte do meu condiscípulo e amigo Martinho José Raposo.

Barcelos, Tip. do Aurora do Cávado, 1897. 14 p.

"Necessidade de uma doca na ilha de S. Miguel", Correio Michaelense, 10 Abr. 1861.

"No tricentenário de Camões", Almanach Litterario e Charadistico, $3^{\circ}$ ano, 1881. p. XLIV.

"Normandia e Bretanha", Europa Pittoresca, 1, Paris, 1881. p. 1-30. 
Obras completas. Vol. III. Filosofia. Org., introde notas de Joel Serrão. Lisboa, Universidade dos Açores/Ed. Comunicação, 1991. LI+271 p.

Oliveira Martins. $O$ crítico litterario. $O$ economista. o historiador. $O$ publicista. $O$ político. Lisboa, Tip. da Companhia Nacional Editora, $1894.52+2 \mathrm{p}$.

O que é a Internacional? (O Socialismo contemporâneo - O programa da Internacional - A organização da Internacional - Conclusões). Lisboa, Tipografia do Futuro, 1871. 30 p. (Saiu anónimo).

O que é a Internacional?. Lisboa, Ulmeiro, 1980. 47 p.

"O que toda a gente vê ou a política n'uma lição", Tira-Teimas, 1, Coimbra, Nov. 1861. p. 3-4.

O que toda a gente vê ou a politica numa lição. Barcelos, Tip. do Aurora do Cávado, 1894. $12 \mathrm{p}$

"Organização", O Pensamento Social, 3, Lisboa, Março 1872. (Saiu anónimo).

"A Patria (Fragmento de um livro) - Ao meu bom amigo Augusto Bicudo Correia", O Phosphoro, 5, Coimbra, 1861.

A Patria (Fragmento de um livro) - Ao meu bom amigo Augusto Bicudo Correia. Barcelos, Tip. do Aurora do Cávado, 1894. 12 p.

"O patriotismo e os Lusíadas. (Fragmento)", Circulo CamonianoRevista Internacional, 2, Porto, 1889-1890 p. 144-154.

"O pensamento social", O Pensamento Social, 1, Fev. 1872. (Saiu anónimo).

"O pensamento social", Seara Nova, 18, Lisboa, 1933. p. 93.

A philosophia da natureza dos naturalistas. Pref. de Eugénio V. P. do Canto e Castro. Ponta Delgada, Tip. Editora do Campeão Popular, 1894. XIV+43 p.

A philosophia da natureza dos naturalistas. Pref. de Eugénio V.P. do Canto e Castro. Ponta Delgada, Typ. Lit. Ferreira, 1901. XIV+52p. A poesia na actualidade - A propósito da "Lira Íntima" do Sr. Joaquim de Araújo. Estudo crítico. Porto, Oficina Tipográfica de João Eduardo Alves, $1881.20 \mathrm{p}$.

A poesia na actualidade: a propósito da Lira Íntima do Sr. Joaquim de Araújo. Estudo crítico. Porto, Typ. Elzeviriana, 1882. 20 p.

A poesia na actualidade. Pref. de Júlio Henriques. Lisboa, Fenda Edições, 1988.

"A política do socialismo", $O$ Pensamento Social, 16, Lisboa, Jul. 


\section{Elementos para uma bibliografia}

1872. (Saiu anónimo).

Portugal perante a Revolução de Hespanha. Considerações sobre o futuro da política portugueza no ponto de vista da democracia ibérica. Lisboa, Tip. Portugueza, 1868. 39 p.

Programma da "Revista Occidental", 1874.

"Programa do 'Rebate'. A que vimos", Nova Alvorada, $4^{\circ}$ Anno, $n^{\circ} 9$, Vila Nova de Famalicão, 1 Dez. 1894. p. 179.

Programa do "Rebate" - A que vimos. Barcelos, Tip. do Aurora do Cávado, 1896. 15 p.

"A propósito d'um poeta", $O$ Phosphoro, Coimbra, 1861, 7, p. 56-57; 9, p. 73-74; 12, p. 98-100.

Prosas. Coimbra, Imprensa da Universidade, 1923-1931. 3 vols.

As Prosas de Antero de Quental. Um tesouro pouco conhecido. Sel., pref. e notas de Víctor de Sá. Braga, Edições Futuro, (1942). 160 p. Prosas da época de Coimbra. Ed. crítica por António Salgado Júnior. Lisboa, Sá da Costa, 1973. 363 p.

Prosas dispersas. Org. Rui Belo. Lisboa, Editorial Presença, 1966. $363 \mathrm{p}$.

Prosas publicadas entre os anos de 1859-1881. Coimbra, Imprensa da Universidade, 1923-26. 2 vols.

Prosas sócio-políticas. Publ. e apres. por Joel Serrão. Lisboa, Imprensa Nacional-Casa da Moeda, 1982. 481 p.

"Protesto contra o encerramento da sala das Conferências Democráticas", in Anthero de Quental. In Memoriam, Porto, Mathieu Lugan Ed. 1896. p. XX

"Questão romana", Gremio Alentejano, 27, Coimbra, 10 Abr. 1862. Questão romana. Barcelos, Tip. do Aurora do Cávado, 1896.14 p.

"A República", A República-Jornal da Democracia Portuguesa, 1, 11 Maio 1870. (Saiu anónimo).

"A República e o socialismo", Seara Nova, 18, Lisboa, 1933. p.157. "Resposta aos jornais católicos", Jornal do Commercio, 22 Jul. 1871. Resposta aos jornais católicos. Barcelos, Tip. do Aurora do Cávado, 1895. $36 \mathrm{p}$.

"Revistas litterarias de Coimbra. 1861", Revolução de Setembro, $\mathrm{n}^{\circ}$ 5915, 26 Jan. 1862. (ass. Raymundo Castromino).

Sá de Miranda. Com uma carta ácerca da 'Bibliografia camiliana' de Henrique Marques por Joaquim de Araújo. Lisboa, Typ. da Companhia Nacional Editora, 1894. 38 p. 
"Saudação ao Príncipe Humberto", Tribuno Popular, 25 Out. 1864.

"O sentimento da imortalidade", O Instituto, 13(2), Coimbra, 1866. p. 39-43.

O sentimento da imortalidade - Carta ao sr. Anselmo de A. Barcelos, Tip. do Aurora do Cávado, 1895.34 p.

Sobre o "Tasso" de Cândido de Figueiredo. Barcelos, Tip. do Aurora do Cávado, 1896.12 p.

"Sobre traduções (Depois de ler as "Recreações Poéticas" do sr. F. Castro Freire", O Phosphoro, 11, Coimbra, 1861. p. 84-87.

Sobre traduções (Depois de ler as "Recreações Poéticas" do sr. F.

Castro Freire). Barcelos, Tip. do Aurora do Cávado, 1894. 22 p.

"O socialismo e a moral", Seara Nova, 555, Lisboa,1938. p. 202.

"Socialismo e philantropia", Beja-Creche, no único, Coimbra, 1885.

Socialismo e philantropia. Barcelos, Tip. do Aurora do Cávado, 1896. $16 \mathrm{p}$.

Soldados da revolução. Barcelos, Tip. do Aurora do Cávado, 1896. 16 p.

"O talento e a vontade", Consagração, no único, Porto, 1886.

"Tendencias Geraes da philosophia na segunda metade do seculo XIX", Revista de Portugal, 2, 1890. p. 5-20, 149-171, 281-306.

Tendências gerais da filosofia na segunda metade do séc. XIX. Pref. e notas por Leonel Ribeiro dos Santos. Lisboa, Ulmeiro, 1982. 112 p.

Tendencias gerais da filosofia na segunda metade do século XIX. Apres., org. e notas de Leonel Ribeiro dos Santos. $2^{\mathrm{a}}$ ed.. Lisboa, Ed. Comunicação, 1988. 162 p.

Tendências gerais da filosofia na segunda metade do século XIX. Fac simile do autógrafo. Estudo de Joel Serrão. Leitura de Ana Maria Almeida Martins. Lisboa, Fundação Calouste Gulbenkian, 1991. $141 \mathrm{p}$.

Tendências novas da poesia contemporânea (A propósito da "Alma Nova" do Sr. Guilherme de Azevedo) (1871). Ponta Delgada, Tip. Minerva, 1893. $22 \mathrm{p}$.

Tendências novas da poesia contemporânea (A propósito das "Radiações da Noite" do Sr. Guilherme de Azevedo). Barcelos, Tip. do Aurora do Cávado, $1895.20 \mathrm{p}$.

"Teoria do socialismo", O Pensamento Social, 34, Lisboa, 8 Dez. 1872. (Saiu anónimo).

"Teoria do socialismo, evolução política e económica das sociedades 


\section{Elementos para uma bibliografia}

da Europa por J.P. de Oliveira Martins", Diário Popular, 24 Fev. 1873.

"Testamento de Antero de Quental", Nova Alvorada, anno 8, n 5, Vila Nova de Famalicão, Set. 1898. p. 133-134.

Testamento filosófico de Antero de Quental (Antologia). Pref. e not. de Sant'Ana Dionísio. Lisboa, Seara Nova, 1946. 208 p. il.

Textos doutrinais e correspondência. Lisboa, Círculo de Leitores, 1987. $340+6 \mathrm{p}$.

Ultimato de 11 de Janeiro. Barcelos, Tip. do Aurora do Cávado, 1896. $12 \mathrm{p}$.

"Uma edição crítica de Sá de Miranda", Nova Alvorada, $3^{\circ}$ Anno, $\mathrm{n}^{\circ} 8$, Vila Nova de Famalicão, 1 Nov. 1893. p. 59-61.

Uma edição crítica de Sá de Miranda. Barcelos, Tip. do Aurora do Cávado, 1894. 26 p.

"Veneza", Europa Pittoresca, 1, Paris, 1881. p. 60-87.

\section{EPISTOLOGRAFIA:}

"Autobiographia de Anthero de Quental (Carta ao sr. Wilhelm Storck)", Circulo Caminiano-Revista Internacional, 2, Porto, 1889-1890. p. 132-142.

"Carta a Bulhão Pato", Nova Alvorada, $5^{\circ}$ anno, $n^{\circ} 7$, Vila Nova de Famalicão, Out. 1895. p. 52.

"Carta inédita a Carlos Cirilo Machado", Ilustração, Ano 1, n 7, 1 Abr. 1926. p. 34.

"Carta inédita de A. de Quental sobre 'O crime do padre Amaro' e dirigida a Eça de Queirós, in E. Queirós, $O$ Crime do padre Amaro. Lisboa, Livros do Brasil, 1969. p. 7-9.

"Carta a João Lobo de Moura acompanhada de dois sonetos do poeta 'Inania regna' e 'Euthanasia"', Revista de História, 8, Lisboa, 1919. p. 67-69.

"Carta ao Sr. Carlos de Lemos", Nova Alvorada, Anno 1, n 5, Vila Nova de Famalicão, 1 Set. 1891. p. 45.

"Cartas (a António de Azevedo Castelo Branco; a Jaime Magalhães Lima)", Revista de Portugal, 2, Coimbra, 1938. p. 161-165.

Cartas a António de Azevedo Castelo Branco. Pref. e notas de Adolfo Casais Monteiro. Lisboa, Ed. Signo, 1942. XXXII+112 p.

"Cartas (a Alice Moderno, João de Deus, Joaquim de Araújo, Frederico 
Diniz Ayala)", Nova Alvorada, Anno 3, n 6, Vila Nova de Famalicão, 1 Set. 1893. p. 43-44.

"Cartas a João de Deus", Nova Alvorada, $5^{\circ}$ anno, nº 6 , Vila Nova de Famalicão, Set. 1895. p. 46.

"Cartas a Joaquim de Araújo". Publ. de Manuel Lopes de Almeida, Arquivo de Bibliografia Portuguesa, Coimbra, 1959, 19-20. p. 113-150; 1960, 21-22. p. 27-47.

Cartas ao Dr. Lôbo de Moura, com um artigo sobre aquele ilustre magistrado e uma carta à Exm ${ }^{a}$ Senhora D. Ana Lobo de Moura, por José T. da Silva Bastos. Coimbra, Imprensa da Universidade, 1921. IX+45 p.

"Cartas de Antero de Quental", in Sebastião Magalhães de Lima, $O$ Socialismo na Europa, Lisboa, Companhia Nacional, 1892. 369 p.

"Cartas de Antero de Quental. Notas de Ruy Galvão de Carvalho", Portucale, 6, Porto, 1933. p. 159-161.

Cartas de Anthero de Quental. Pref. de João Machado de Faria e Maia. Coimbra, Imprensa da Universidade, 1915. LXVII+320 p.

Cartas de Anthero de Quental. Pról. de Teixeira de Carvalho. $2^{\mathrm{a}}$ ed.. Coimbra, Imprensa da Universidade, 1921. XXV+372 p.

"Cartas de Antero de Quental a Alberto Teles", in Camilo Castelo Branco na cadeia da Relação do Porto. Porto, Livraria Ferreira, 1917. p. 81-97.

Cartas de Antero de Quental a Francisco Machado de Faria e Maia. Pref. e notas de Ruy Galvão de Carvalho. Lisboa, Delfos, 1961. $55 \mathrm{p}$.

"Cartas de Antero de Quental a Jaime de Magalhães Lima. Segundo o texto original". Ed. de Aníbal Ramos, Arquivo do Distrito de Aveiro, 42(165), Aveiro, 1976. p. 3-23 il.

"Cartas de Antero de Quental e sua irmã Ana Guilhermina de Quental", Arquivo de Bibliografia Portuguesa, 33-36, Coimbra, 1963. p. 98116.

"Cartas de Antero de Quental a sua mãe, D. Ana Guilhermina da Maia". Publ. de Manuel Lopes de Almeida, Arquivo de Bibliografia Portuguesa, 12, Coimbra, 1957. p. 161-166.

"Cartas de Antero de Quental ao poeta sueco Goran Bjorkman". Publ. de Manuel Lopes de Almeida, Arquivo de Bibliografia Portuguesa, 13-14, Coimbra, 1958. p. 1-7.

"Cartas de Anthero de Quental (a Manuel Sardenha, José Félix Pereira, 


\section{Elementos para uma bibliografia}

Ana de Quental, Gabriel Pereira, Gaspar de Queiroz Ribeiro, Gen. Sebastião Teles, A.A. da Rocha Peixoto)", A Revista, Anno I, $\mathrm{n}^{\circ}$ 6, Porto, 15 Dez. 1903. p. 97-102.

Cartas: Primeira série (cartas cujo principal assunto é de natureza filosófica). Pref. de António Sérgio. Lisboa, Ed. Couto Martins, 1957. XXIII+160 p.

Cartas de Vila do Conde. Introd., org. e notas de Ana Maria Almeida Martins. Porto, Lelo \& Irmão, 1981. 365 p.

Cartas inéditas a Alberto Sampaio. Transc., org., pref. e notas de Ana Maria Almeida Martins. Lisboa, Publicações O Jornal, 1985. 99 p.

Cartas inéditas de Antero de Quental a Oliveira Martins. Publ. por Francisco de Assis Oliveira Martins com pref. de Joaquim de Carvalho. Coimbra, Imprensa da Universidade, 1931. XI+165 p.

Cartas inéditas de Antero de Quental a Wilhelm Storck. Publ. de Henri Meier. Coimbra, Coimbra Editora, 1935. 23 p.

"Cartas inéditas de Anthero de Quental", Correio dos Açores, Ponta Delgada, 10 Set. 1922. p. 1.

Correspondência de Antero de Quental e Jaime Batalha Reis. Introd., org. e notas de Maria Staack. Lisboa, Assírio e Alvim, 1982. p. $165+8$ p.il.

"Correspondência de Antero de Quental com João de Deus", Revista Illustrada, 1(1), Lisboa, 1890. p. 5.

"De Antero de Quental (a Cândido de Figueiredo)", in Cartas inéditas de oitenta e cinco escritores portugueses da segunda metade do séc. $X I X$ e do primeiro quartel do actual. Pref e not. de Cândido de Figueiredo. Rio de Janeiro, H. Antunes \& C Ed., (1924). p. 7-12. "Dez cartas inéditas de Antero de Quental". Introd. de Manuel Pinto Ferreira de Sousa, Revista Portuguesa de Filosofia, 31(2), Braga, 1975. p. 179-188.

"Doze cartas de Antero de Quental à sua irmã Ana", Portucale, 15 (86-87), Porto, 1942. p. 101-109.

"Duas cartas de 15 de Março e s.d. a Oliveira Martins", in Portugal Contemporâneo. Com uma carta de Alexandre Herculano a D. Pedro II Imperador do Brasil e outras dirigidas ao autor comentando a obra. $6^{\mathrm{a}}$ ed.. Lisboa, Parceria António Maria Pereira, 1925. p. $462-464$.

"Duas cartas de A. de Q. (a Domingos Tarroso e a Sebastião de Magalhães Lima)", Nova Alvorada, $6^{\circ}$ Anno, n 5, Vila Nova de 
Famalicão, Agosto 1896. p. 129-130.

"Lettre à Mr. Maxime Formont", Circulo Camoniano-Revista Internacional, 2, Porto, 1889-1890. p. 129-131.

"Novas cartas inéditas de Antero", Revista Portuguesa de Filosofia, 45(1),Braga, Jan.-Mar 1989. p. 3-19.

Obras Completas. vol. VI Cartas I. 1852-1881. Org., introd. e notas de Ana Maria Almeida Martins. Lisboa, Universidade dos Açores/Ed. Comunicação, $1989.581 \mathrm{p}$.

Obras completas. Vol. VII Cartas II. 1881-1891. Org., introd. e notas de Ana Maria Almeida Martins. Lisboa, Ed. Comunicação/Universidade dos Açores, 1989. $1154 \mathrm{p}$.

"Oito cartas de Antero de Quental à sua irmã Ana", Portucale, 15(8889), Porto, 1942. p. 143-150.

"Quatro cartas de Antero de Quental", Portucale, 14(80-81), Porto, 1941. p. 79-81.

"Uma carta de Anthero de Quental (à Exm ${ }^{\mathrm{a}} \mathrm{Sr}^{2} \mathrm{D}$. Maria Amália Vaz de Carvalho)", Nova Alvorada, Anno 7, Vila Nova de Famalicão, Abr. 1897. p. 8.

"Uma carta inédita", Diário de Coimbra, Coimbra, 16 Abr. 1942. p. 1. "Uma carta de inédita de Antero a Mariano Augusto Machado de Faria e Maia", Correio dos Açores, Ponta Delgada, 20 Abr. 1941. p. 1.

\section{ANTOLOGIAS:}

Antero de Quental. Introd. e seleç̧ão de textos de Anna Maria Moog Rodrigues. Lisboa, Verbo, 1990. 211 p.

Antero de Quental. Pref. e selec. de José Tomás Calvet de Magalhães. Lisboa, Ed. SNI, 1948. 142 p.

Antero de Quental-1842-1891. Pref. e antologia de A.M.B. Machado Pires. Angra do Heroísmo, Direcção Regional dos Assuntos Culturais, $1987.200+8$ p.

Obras de Antero de Quental. Org., pref. e notas de António Sérgio. Lisboa, Couto Martins, 1943. 3 vol. 


\section{VARIA:}

"Carta de Henri Heine a Gerard de Nerval", Século XIX, 7, Penafiel, 23 Mar. 1864. p. 1. (trad.)

"Excertos d'uma tradução do Fausto de Goethe. A Canção do Rei de Tule", $A$ Folha, $3^{\mathrm{a}}$ série, $\mathrm{n}^{\mathrm{o}}$ 1, Coimbra, 1871. p. 6-7.

GOETHE, Johannn Wolfgang von - $O$ rei de Thule. Versões portuguesas por Agostinho de Ornelas... Antero de Quental.... Coimbra, Instituto Alemão da Faculdade de Letras de Coimbra, 1932. $22 \mathrm{p}$.

Introdução a "Cantos na solidão" de Manuel Ferreira da Portela. Barcelos, Tip. do Aurora do Cávado, 1894. 20 p.

Introdução a uma paesia de D. Henriqueta Elisa. Barcelos, Tip. do Aurora do Cávado, $1896.12 \mathrm{p}$.

Thesouro poetico da infancia. Col. e orden. por Antero de Quental. Porto, E. Chardron Editor, 1883. XV+218+IV p.

Thesouro poético da infancia. Colig. e orden. por Anthero de Quental. Porto, Typ. Alliança, 1884. XV+218 p.

Tesouro poetico da infância. $2^{\mathrm{a}}$ ed.. Lisboa, Couto Martins, 1943. 230 p.

Tesouro poético da infância. Col. e ord. por Antero de Quental. Porto, Lello \& Irmão, 1983. 250 p.

Tratado pratico da educação materna pelo abbade Pichenot, arcediago geral da diocese de Sens. Traducção livre. Lisboa, Typ. de Thomaz Quintino Antunes, 1873. 203+5 p. (Trad.)

\section{OBRAS PUBLICADAS NO ESTRANGEIRO:}

"Antero de Quental" in Las mejores poesias liricas de los mejores poetas. Barcelona, Editorial Cervantes, s.d. 71 p.

Ausgewahlte Sonette aus dem Portugesischen verdeutscht von Wilhem Storck. Paderborn und Munster, Verlag von F. Shoningh, 1887. $126 \mathrm{p}$.

Dikter en efteskord ofversattningar af Goran Bjorkman. Norrtelje, s.n. 1895. $32 \mathrm{p}$.

Ditker of versatta af Goran Bjorkman. Upsala, Lundequistka Bokhaudeln, 18.. 52+2 in. p.

Poémes et sonnets d'Anthero de Quental. Trad. en vers français et 
précedés d'une notice biographique et littéraire par Virgile Rossel. Paris, Garnier Fréres, 1911(?).

Poesia e prosa (sonetos completos, poemas e prosa escolhidos).

Selec., pref. e notas de Carlos Filipe Moisés. São Paulo, Cultrix, 1974. 33 p.

Poesia e prosa. Selec. e apresent. de Adolfo Casais Monteiro. Rio de Janeiro, Livraria Agir, 1957. 132 p.

Poesias y prosas selectas. Trad. y notas de Juan Eduardo Zúñiga Sonetos /Edición bilingue) de José António Llardent. Introd. de Óscar Lopes. Madrid, Ediciones Alfaguara, 1986. 503 p.

Prosas escolhidas. Selec. e pref. de Fidelino de Figueiredo. Rio de Janeiro, Edições Livros de Portugal, 1942. 316 p.

Quattro sonetti di Anthero de Quental. Padova, Tip. Fratelli Gallina, 1896. 14 p.

Sixty-four sonnets englished by Edgar Prestage. London, Publ. David Nutt, 1894. XIV+133 p.

Los Sonetos completos de Anthero de Quental. Pref. de Oliveira Martins. Trad. de Emilia Bernal. Madrid, Imp. de G. Hernández y Gaio Sáez, 1926. 235 p.

Los sonetos completos de Antero de Quental. $2^{\mathrm{a}} \mathrm{ed} .$. Santiago do Chile, 1937.

Sonetos completos e poemas escolhidos. Selec., rev. e pref. de Manuel Bandeira. Rio de Janeiro, Livros de Portugal, 1942. X+318 p.

Sonetos escogidos. Selec. de António Sérgio. Santiago de Compostela, Universidad de Santiago de Compostela, 1933. 30 p.

Sonnets and poems of Anthero de Quental. Trad. S. Griswold Moreley. Berkeley, University of California Press, 1922. XXIV+ $+133 \mathrm{p}$.

Sonnets. Trad. de Anne-Maria Quint. Paris, Centre Culturel Portugais, Fondation Calouste Gulbenkian, 1991. (50) p.

Sonetti completi, prima versione italiana.... Messina, Tip. dell'Editore, 1898. CXIX+366 p.

Sonetti. Introd. e notas di Brunello de Cusatis. Palermo, Editrice Novecentos, 1991. $237 \mathrm{p}$.

Tendances générales de la philosophie dans la seconde moitié du XIXe siecle. Trad. par Simone Biberfeld. Pref. de Ana Maria Almeida Martins et Joel Serrão. Paris, Ed. de la Différence, 1991. 95 p.

Traduction de quelques poèmes d'Antero de Quental par Jorge Verdin 
in Poésies portugaises/Cesário Verde. Paris, Imp. Henriot, 1920. $62 \mathrm{p}$.

Zara, versi scritti da Anthero de Quental, tradotti de parecchi. Noterelle di E. Teza. Genova, Tipografia R. Istituto Sordo Muti, 1895. $24+2 \mathrm{p}$.

Zara, versi sopra un sepolcro scritti da Anthero de Quental, tradotti da parecchi. Notorelle de E. Teza. $2^{a}$ ed.. Genova, Typografia R. Istituto Sordo Muti, 1896. 20 p.

\section{OBRAS SOBRE ANTERO DE QUENTAL}

ABREU, G. de Vasconcelos - "O tedio-doloroso", in Anthero de Quental. In Memoriam. Porto, Mathieu Lugan, ed., 1896. p. 31-35 AFONSO, João - Antero de Quental e o pensamento da Revolução Nacional. Lisboa, Edições Panorama, 1967. 93 p.

AGUILERA, Caldelas y - "Anthero de Quental", Nova Alvorada, Anno 1, nº 7, Vila Nova de Famalicão, 1 Nov 1891. p. 63.

ALBERGARIA, Jacinto Soares de $-A$ inquietude de Antero. Ponta Delgada, Tip. Insular, 1976. $31 \mathrm{p}$.

ALBUQUERQUE, C. Andrade - "Em lembrança de Anthero", in Anthero de Quental. In Memoriam. Porto, Mathieu Lugan, Ed., 1896. p. 73-93

ALBUQUERQUE, Mário - "O drama de Antero de Quental", Acção realista, 2(22), Lisboa, 1925. p. 166-169.

ALIBERT, Jacques - "Antero de Quental: le poete socialiste du Portugal", Europe, Paris, Ano 25, n. ${ }^{\circ} 18,1947$. p. 135-139.

- "Proudhon, Antero de Quental e o 'mal' do século XIX", Estudos, 256, Coimbra, 1947. p. 171-173.

ALMEIDA, António José de - "Antero", Diário dos Açores, Ponta Delgada, 18 Abr. 1929. p. 1.

ALMEIDA, António Pinto de Magalhães - "Um inédito de Anthero", Nova Alvorada, Anno 2, n 5, Vila Nova de Famalicão, 1 Jul. 1892. p. 151-152.

ALMEIDA, António Ramos de - Antero de Quental. Infancia e juventude. Porto, Livraria Latina Ed., 1943. 2 vols.

- Antero de Quental: apogeu, decadência e morte. Porto, Livraria Latina Ed., 1944. 124 p. 
- O socialismo proudhoniano de Antero de Quental. Porto, Edições da Revista Bandarra, 1957. 23+2 p.

ALMEIDA, Augusto - "Bibliographia antheriana", Nova Alvorada, Anno 7, nº 7, Vila Nova de Famalicão, 1897. p. 51-53.

- Bibliografia anteriana. Exame de recentes afirmações com duas cartas de Camilo Castelo Branco. Famalicão, 1898.

ALMEIDA, Lourenço Heitor Chaves de - "La philosophie de la mort chez Antero de Quental", in Pensée ibérique et finitude: essais sur le temps et la mort chez quelques écrivains espagnols et portugais contemporains. Toulouse, Publications de l'Université de Toulouse-Le Mirail, 1972. $10 \mathrm{p}$.

ALMEIDA, M. Duarte - "Na romagem do absoluto: a grande sombra familiar e amiga de Antero de Quental", Nova Alvorada, Vila Nova de Famalicão, Ano 1, n. ${ }^{\circ}$ 7, 1891. p. 65.

-"O suicídio de Anthero (tentativa de investigação das causas que o produziram)", in Anthero de Quental. In Memoriam. Porto, Mathieu Lugan, Ed., 1896. p. 349-365.

ALMEIDA, Renato - "Antero de Quental", in Em relevo. Rio de Janeiro, Of. Typographicas Apollo, 1917. p. 7-22.

ALMEIDA, Vieira de - "Antero de Quental", Bulletin des Études Portugaises de l'Institut Français au Portugal, 5(1), Lisbonne, 1938. p. 1-12.

- "Antero de Quental", Ocidente, 17(49), Lisboa, 1942.p. 5-12.

- "Entre as formas incompletas", Seara Nova, 20, Lisboa, 1934. p. 347-350.

ALVES, Jose - "Analyse rhétorique et thématique du sonnet 'Em Viagem' d'Antero de Quental. 'Em Viagem' ou la recontre avec la mort fraternelle", Arquivos do Centro Cultural Português, 19, Paris, 1983. p. 699-717.

- Antero de Quental. Les mortelles contradictions. Aspects comparatifs avec Charles Baudelaire et Edgar Poe. Paris, Fondation Calouste Gulbenkian, 1982. XXII+524 p.

- "Essai de caractériologie d'Antero de Quental", Sillages, 3, Poitiers, 1973. p. 77-127.

- "Métasémèmes et métalogisme dans un sonnet de Antero de Quental", Sillages, 2, Poitiers, 1972. p. 65-96.

ALVES, Oswaldo - "Antero de Quental", Aventura, 2, Lisboa, 1942. p. 53-55. 
AMARAL, Carlos Eduardo Pacheco - Antero Tarquínio de Quental. s.l., s.n., 1983.

Análise crítica, rápida, despretenciosa feita ao folheto intitulado Garrett, Castilho, Herculano e a Escola Coimbrã etc. pelo sacristão de uma Ermida. Lisboa, Typ. 20, rua da Encarnação, 1886. 16 p.

ANDRADE, Abel de - "Antero de Quental e a synthese philosophica", in A synthese cartesiana. Influencia do cartesianismo sobre o racionalismo. Coimbra, Imprensa da Universidade, 1892. p. 76-81 .

ANDRADE, Anselmo de - "Antero de Quental", in Alguns homens ilustres de Portugal. Lisboa, Imprensa da Livraria Ferin, 1929. p. 63-94.

- "O sonho do poeta", in Anthero de Quental. In Memoriam. Porto, Mathieu Lugan, Ed., 1896. p. 319-335.

ANDRADE, Miranda de - "Luís de Magalhães e Antero de Quental", Gazeta Literária, s. 3, n. ${ }^{\circ}$ 2, Porto, Out. 1969. p. 6; 12-13.

ANGLIN, João H. - "Antero de Quental", in Leituras para os meus alunos. Ponta Delgada, Tip. do "Correio dos Açores", 1946. p. 23$-28$.

- "Antero de Quental. Nótulas para a sua biografia", Correio dos Açores, Ponta Delgada, 11 Set. 1931. p. 1.

- "Antero de Quental", Ocidente, 17(50), Lisboa, 1942. p. 158-161 .

Anteriana. Ano do centenário do nascimento de Antero de Quental. Ponta Delgada, Sep. do Semanário A Ilha, 1942. 50 p.

A Antero. s.l., Externato do Infante, 1964.

"Antero e Bruno", in Portugal. Breviário da Pátria para os portugueses ausentes. Lisboa, Edições do SNI, 1946. p. 270-271.

Antero. Ele próprio na vida e na obra. Exposição. Ponta Delgada, Biblioteca Pública e Arquivo de Ponta Delgada, 1991. 256 p.

Antero de Quental. Bibliografia e Iconografia. Lisboa, Câmara Municipal de Lisboa, 1991. 227 p.

Antero de Quental. In Memoriam. Porto, Mathieu Lugan, Ed., 1896. $527+X C V I+X X X I$ p. il.

Antero de Quental. 1842-1891. Apres. de Maria Leonor Machado de Sousa. Lisboa, Biblioteca Nacional, 1991. 135 p.

Antero de Quental e Ramalho Ortigão: carta a A. d'Azevedo Castelo Branco. s. 1., s. n., 1866. 15 p. 
"Antero de Quental", Correio da Noite, Lishoa, 22 Set. 1891. p. 1.

"Antero de Quental", Diário Ilustrado, Lisboa, 23 Set. 1891. p. 1.

"Antero de Quental", Jornal da Noite, Lisboa, 22 Set. 1891. p. 1.

"Antero de Quental", Nova Alvorada, Anno 1, n⿳ 11, Vila Nova de

Famalicão, 1 Março 1892. p. 105-106.

"Antero de Quental", O Portuguez, 25 Set. 1891.p. 1.

"Antero de Quental", A Província, Porto, 23 Set. 1891. p. 1.

"Antero de Quental", Jornal da Manhã, Porto, 23 Set. 1891. p. 1.

"Antero de Quental", Jornal do Porto, 24 Set. 1891. p. 1.

"Anthero de Quental", Revista de Portugal, 4, Lisboa, 1892. p. V-VII.

"Antero de Quental", O Século, 23 Set. 1891.p. 1.

"Antero de Quental", A Tarde, 23 Set. 1891. p. 1.

"Antero de Quental", 0 Tempo, 23 Set. 1891.p. 1.

"Antero de Quental", A Tribuna, 23 Set. 1891. p. 1.

"Antero de Quental", A Voz Pública, 23 Set. 1891. p. 1.

"Antero de Quental. O ano de todas as programações", JL-Jornal de Letras, Artes e Ideias, Lisboa, Ano X, 15 Jan. 1991. p. 6.

"Antero de Quental und sein Verhaltnis zum deutschen Geistesleben", Iberoamerican Blatter, 6(5-7), 1934.

Antero e os tempos da Escola. Exposição de artes plásticas. Ponta

Delgada, Escola Secundária de Antero de Quental, 1991. 159 p.

ARANHA, Pedro Venceslau Brito - $O$ bom-senso e o bom-gosto:

humilde parecer. Com uma carta do Senhor A. F. de Castilho.

Lisboa, Livraria A. M. Pereira, 1866. 15 p.

ARAÚJO, Joaquim de - Bibliographia antheriana. Resposta a alguns reparos do sr. Delphim Gomes. Coimbra, Tribuno Popular, 1896. $14 \mathrm{p}$.

- Bibliografia antheriana. Resposta aos srs. Delfim Gomes e José

Pereira de Sampaio. Génova, Tip. R. Istituto Sordo-Muti, 1897. 56 p. il.

- "Ensaio de bibliografia anteriana", in Antero de Quental. In Memoriam. Porto, Mathieu Lugan. Ed., 1896. p. I-XCVI.

- In morte di Anthero. Messina, Tipi de l'Autore, 1892. 12 p.

- In morte di Anthero. Bergamo, Ist. Italiano d'Arti Grafiche, $1897.8 \mathrm{p}$.

- Na morte de Anthero. Porto, Tip. da Rua do Bonjardim, 1891.

$12 \mathrm{p}$.

- On the death of Anthero de Quental. s.l., Privately Printed, 
1893. (12) p.

ARAÚJO, Luís de - "Antero - o repto da ética", Revista da Faculdade de Letras, $2^{\text {a }}$ série, 8, 1991. p. 51-56.

ARRIAGA, Manuel d' - "Ao correr da penna (Notas)", in Anthero de Quental. In Memoriam. Porto, Mathieu Lugan, Ed., 1896. p. 95-110 .

ARROIO, António - A Viagem de Antero de Quental à América do Norte. Porto, Renascença Portuguesa, 1916. 71+9 p.

ATKINSON, Dorothy M. - "As imagens de Antero. Resumo", Ocidente, 73(354), Lisboa, 1967. p. 149-156.

- "As imagens nas 'Odes Modernas' de Antero de Quental", Ocidente, 69(330), Lisboa, 1965. p. 145-155.

- "As imagens nos sonetos de Antero de Quental", Ocidente, 59(268), Lisboa, 1960. p. 105-112.

- "As imagens religiosas na poesia de Antero de Quental", Ocidente, 71(343), Lisboa, 1966. p. 237-245.

AZEVEDO, Maria Teresa Schiappa de - Recensões críticas. Sep. de Hvmanitas, vol. 25-26. Coimbra, Instituto de Estudos Clássicos, 1974. p. 327-334.

AZEVEDO, Visconde de - Algumas observações sobre a carta que acerca das Conferências do Casino escreveu o sr. Alexandre Herculano. Porto, Typ. da Palavra, 1873. 42+2 p.

B., J. - "Antero praxista", Diário de Coimbra, Coimbra, 16 Abr. 1942. p. 1-2.

- "Revela-se o processo académico em que Antero, com outros estudantes de Coimbra foi condenado a oito dias de prisão. As principais peças do processo", Correio dos Açores, 11 Set. 1931. p. $1-4$.

BAIÃO, António - "O avô de Anthero", in Episódios dramáticos da Inquisição portuguesa. Rio de Janeiro, Ed. do Annuario do Brasileiro, 1924. p. 146-147.

BANDEIRA, Manuel - "Antero de Quental", Seara Nova, 39, Lisboa, 1942. p. 3.

- "Excerpto dum prefácio a uma selecção de poemas de Antero", Seara Nova, 777, Lisboa, 1942. p. 3-6.

- Prefácio aos Sonetos Completos de Antero de Quental. Rio de Janeiro, Ed. Livros de Portugal, 1942. p. 5-26. e CORTESÃO, Jaime - Glória de Antero. Lisboa, Seara Nova, 
1943. $47 \mathrm{p}$.

BARBOSA, Anibal Cymbron Bettencourt - Projecçãonoestrangeiro de dois poetas micaelenses. Ponta Delgada, Instituto Cultural de Ponta Delgada, 1967. 38 p.

BARBOSA, Manuel - "Antero socialista", in Figuras \& perfis literários. Ribeira Grande, Manuel Barbosa, 1983. p. 171-176.

BARREIRA, Cecília - "Alguns aspectos do ideário político de Antero", Diário de Notícias, 24 Maio 1992. p. 12.

- "Cem anos de reflexão", Diário de Notícias, Caderno 2, Lisboa, 12 Maio 1991. p. 2.

- "Paixão e devoção de uma anteriana: Ana Maria Almeida Martins", Diário de Notícias. Supl. "Cultura", Lisboa, 23 Mar. 1986. p. IV-V.

BARRETO, G. Moniz - Ensaios de crítica. Lisboa, Bertrand, 1944. XLII+358 p.

- A literatura portuguesa no século XIX. Lisboa, Editorial Inquérito, 1940. p. 50-53.

BARRETO, Manuel - "Antero de Quental", Revista de História, Factos e Notas, 12, Lisboa, 1923. p. 237.

BARROS, João de - "Antero e o povo", in Presenças eternas. Lisboa, Sá da Costa, 1943. p. 79-82.

BASTO, A. de Magalhães - "Antero, Teófilo e o vélho Café da Águia de Oiro", in Homens e casos de uma geração notável. Porto, Livraria Progredior Editora, 1938. p. 91-97.

BASTOS, J. F. Teixeira - "Os Sonetos de Antero de Quental", Revista de Estudos Livres, Lisboa, 1885-1886. p. 541-554.

BATTELLI, Guido - Antero e Carducci. Le "Saudades paganas" di Antero de Quental e la poesia di Giosué Carducci. Coimbra, Coimbra Editora, 1930. 16 p.

- "Antero e Leopardi", Diário dos Açores, Ponta Delgada, 18 Abr. 1929. p. 5.

BEAU, Albin Eduard - "Antero de Quental 'discípulo da Alemanha filosofica e poética' ", Via Latina, 10, Coimbra, 30 Abr. 1942.p. 16. - Antero de Quental e a idea de morte", in Estudos, Coimbra, Universidade de Coimbra, 1964, vol. 2. p. 305-323.

- "Antero de Quental perante a Alemanha e a França. Reflexões e reacções", in Estudos, Coimbra, Universidade, 1964, vol. 2. p. 325-352. 


\section{Elementos para uma bibliografia}

- Antero de Quental in seiner Auseinandersetzung mit dem deutshen und dem franzoesischen. Sep. de Revue de Littérature Comparée. Paris, Oct.-Dec. 1938. p. 702-720.

- "Die Sonette von Antero de Quental", in Aufsatze zur portugiesischen Kultugeschichte. Munster Westfalen, Aschendorffsche Verlagsbuchhandlung, 1961, vol. II. p. 99-151

- "Os Sonetos de Antero de Quental", in Estudos, vol. 2. Coimbra, Universidade de Coimbra, 1964. p. 241-304.

BELARD, Francisco - "Encontros com Antero", Expresso. Revista, Lisboa, 6 Jul.1991.p. 90.

BELÉM, António Manuel - Horácios e curiácios ou mais um ponto e vírgula na actual questão literária. Lisboa, Tip. da Sociedade Tipográfica Franco-Portuguesa, 1866. 12 p.

BELL, Aubrey F. G. - "Anthero Tarquínio de Quental", in Portuguese bibliography. Oxford, Humphrey Milford, 1922. p. 325-328.

BELO, José Maria - "A correspondência de Antero de Quental", in À margem dos livros. Rio de Janeiro, Anuário do Brasil, 1923.p. 23-29 .

BENSAUDE, Alfredo - "Antero de Quental. Reminiscencias", Correio dos Açores, Ponta Delgada, 10 Set.1922. p. 2 il.

BENSAUDE, Jose - "A morte de Antero", Seara Nova, 16(298), Lisboa, 1932. p. 147-155.

BERARDINELLI, Cleonice - "Antero de Quental e Fernando Pessoa - Uma tentativa de aproximação", Cadernos da PUC, 1, Rio de Janeiro, Agosto 1969.

- "A bifronte idéia de Antero de Quental", Arquivos do Centro Cultural Português, 23, Paris, 1987. p. 709-726.

- "A Geração de 70 e a Geração de Orpheu", in Estudos de Literatura Portuguesa. Lisboa, Imprensa Nacional-Casa da Moeda, 1985. p. 159-177.

- "Os sonetos de Antero: tentativa de análise estrutural", Revista da Faculdade de Letras de Lisboa, 13, Lisboa, 1971. p. 61-79.

BERNARDES, Diogo - Os Coimbrões: Questão em que também entra pelos cem reis José Francisco, caiador da Rainhado Congo.... Lisboa, Typ. de José Manuel Pereira, 1866. 15 p.

BERNARDINO, José - "Anthero de Quental e o Principe Humberto (uma rectificação)", Nova Alvorada, Anno 1, n 11, Vila Nova de Famalicão, 1 Mar. 1892. p. 105-106. 
BERRINI, Beatriz - "Pessoa e Antero", Persona, 11-12, Porto, Dez. 1985. p. 19-26.

BETTENCOURT, Humberto - "A estátua de Antero", Correio dos Açores, Ponta Delgada, 10 Set. 1922. p. 2 e 3.

BETTENCOURT, Rebelo de - "O drama de Antero", in $O$ mundo das imagens. Lisboa, Ed. Ressurgimento, 1928. p. 13-18.

- A lição de Antero. O drama do poeta confessado em seus versos. Ponta Delgada, Typ. do Diário dos Açores, 1924. 7 p.

- "Notas sobre a morte de Antero", Diário dos Açores, Ponta Delgada, 18 Abr. 1929. p. 5.

- "A 'Serenata' de Antero", Correio dos Açores, Ponta Delgada, 2 Out. 1921.p. 1.

- O verdadeiro Antero. No $1^{\circ}$ centenário de Antero de Quental. 18 de Abril de 1842-18 de Abril de 1942. Lisboa, Empresa Literária Universal, 1942. $78 \mathrm{p}$.

BETTENCOURT, Urbano - "Antero, açoriano. Vozes em volta", Revista de História das Ideias, 13, Coimbra, 1991. p. 221-229.

- O gosto das palavras. Angra do Heroísmo, Secretaria Regional de Educação e Cultura, 1983. 170+7 p.

BJORKMAN, Goran - Anthero de Quental ett Skaldeportratt. Upsala, Ludequistska Bokhandeln, 1894. 83 p.

BORGES, Carlos - Pena e espada, duas palavras àcerca da literatura d'hoje de J. D. Ramalho Ortigão. Porto, Typ. Lusitana, 1866. $16 \mathrm{p}$.

BOTELHO, Abel Acácio - "Blasfémias de um crente. Carta ao sr. Antero de Quental", Novidades, Lisboa, 15 Jan. 1888.

BOTELHO, Luís - "Anthero de Quental (1886)", Nova Alvorada, Anno 1, nº 7, Vila Nova de Famalicão, 1 Nov. 1891. p. 73-75.

- "Anthero de Quental", in Farrapos. Jornal de um impressionista. Porto, Livraria Universal Magalhães \& Moniz, Editores, 1892. p.1-8.

- "Morte de Anthero de Quental", in Farrapos. Jornal de um impressionista. Porto, Livraria Universal Magalhães \& Moniz Editores, 1892. p. 231-236.

BRAGA, Luís de Almeida - "Um profeta da República", in Sob o pendão real. Lisboa, Edições Gama, 1942. p. 133-145.

BRAGA, Teófilo - "O amor de Antero de Quental", A Águia, 3, 2a série, Porto, 1915. p. 49-54. 
- "Anthero de Quental (Periodo do protesto da eschola de Coimbra", in As modernas idéias na litteratura portugueza, vol. II. Porto,

Livraria Internacional de Ernesto Chardron, 1892. p. 96-223.

- "Anthero de Quental", in In Memoriam Rodrigues de Freitas.

(Commemoração biographica). Lisboa, Typ. Companhia Nacional Editora, 1896. p. 5-72.

- "Composição inédita de Anthero", Nova Alvorada, Anno 1, $\mathrm{n}^{\circ}$

7, Vila Nova de Famalicão, 1 Nov. 1891. p. 66-67.

- História da Universidade de Coimbra. vol. IV. Lisboa, Tip. da

Academia Real das Sciencias, 1902. p. 488-496.

- "A mulher e o sentimento do amor em Antero de Quental",

Nação Portuguesa, série II, 5, Nov. 1922.

- "O snr. Anthero de Quental e as considerações sobre a philoso-

phia da historia da litteratura portugueza", in Os críticos na história

da litteratura portugueza. Exame das affirmações dos Snrs Oliveira Martins, Anthero de Quental e Pinheiro Chagas. Porto, Imprensa Portuguesa, Editora, 1872. p. 26-40.

- Soluções positivas da política portuguesa. Do advento evolutivo das idéias democráticas. Lisboa, Livraria Chardron de Lello \& Irmão, 1912. 2 vols.

BRANDÃO, Mário - Antero de Quental, estudante. Documentos. Coimbra, Biblioteca Geral da Universidade de Coimbra, 1957. $312 \mathrm{p}$.

- "Antero de Quental, estudante", Boletim da Biblioteca da Universidade de Coimbra, 23, Coimbra, 1958. p. 106-416.

BRASIL, Reis - Antero, vate da humanidade. Santarem, Tip. Escolar, 1956. $74 \mathrm{p}$.

BRAZETTE, Manuela - "Viver na esperança - perder a esperança", Estados Limites. V Seminário de Psicologia e Psicopatologia clínica. Lisboa, Hospital Miguel Bombarda, 1989. p. 23-35.

BREYNER, Tomás de Melo - "Como eu conheci Antero de Quental", Diário dos Açores, Ponta Delgada, 18 Abr. 1929. p. 1 e 4.

BRITO, Ferreira de - "Antero de Quental e os modelos culturais europeus", in Estudos de História Contemporânea Portuguesa. Homenagem ao Professor Víctor de Sá. Lisboa, Livros Horizonte, 1991. p. 371-376.

- "Os modelos culturais europeus", Diário de Notícias, Caderno

2: "Antero de Quental, O príncipe da agonia", Lisboa, 12 Maio 
1991. p. 8-9.

BUCICH, Antonio J. - "Eça de Queiroz y Anthero de Quental", in En pos de Eça de Queiroz. Buenos Aires, s.n., 1939. p. 15-32.

BUESCU, Helena Carvalhão - "Reflexões sobre arte-poesia e o 'nosso tempo' em Antero de Quental", Cadernos da Faculdade de Letras de Lisboa, 11, Lisboa, 1978. p. 108-121.

BUSTORFF, A. - Antero de Quental. Impressões fugitivas. Lisboa, Typ. Mendonça, 1912. 14 p.

CABRAL, Alexandre - "Contradições Anterianas", A Capital, Literatura e Arte. Lisboa, 28 Ago. 1968. p. 1-2.

CABRAL, António - Glória e sombras de Eça de Queirós. Lisboa, 1941.

CABRAL, Eunice - "Revolução e desencanto", Diário de Notícias, Caderno 2. "Antero de Quental, O príncipe da agonia", Lisboa, 12 Maio 1991.p. 2.

CAMACHO, Brito - "Opiniões sobre Antero de Quental. O pessimismo de Antero", A Ilha, Ponta Delgada, 19 Abr. 1941. p. 6; 10.

CÂMARA, Filomeno da - "Annos de Coimbra", in Anthero de Quental. In Memoriam. Porto, Mathieu Lugan, Ed., 1896. p. 315$-318$.

CÂMARA, Manuel da - Antero de Quental e a sua morte. Ponta Delgada, Edição do Diário dos Açores, 1930. 50 p. il.

- "Na vespera da morte de Anthero de Quental", Correio dos Açores, Ponta Delgada, 10 Set. 1922. p. 1 e 4.

CAMPOS, Agostinho de - "Sonnets and poems of Anthero de Quental", Lusitania, 3(8), Lisboa, 1925. p. 283-288.

CAMPOS, Fernando - "O testemunho de Antero", in No saguão do liberalismo. Lisboa, Ed. José Fernandes Júnior, 1935. p. 105-119. - "O testemunho de Antero", Nação Portuguesa, 8(3), Lisboa, 1933. p. 141-155.

CANDELARIA, Moreira - "O drama de Antero", Correio dos Açores, Ponta Delgada, 24 Abr.1942. p. 1-2.

CÂNDIDO, Manuel - Antero e Roberto Mesquita. Vila Franca do Campo, Ed. Ilha Nova, 1986. 26+3 p.

- "Aspectos da crítica leornardina ao pensamento filosofico de Antero", Revista Portuguesa de Filosofia, 47(2), Braga, 1991. p. 293-310.

- "Leonardo Coimbra e Antero de Quental", Revista Portuguesa 
de Filosofia, 45(1), Braga, 1989. p. 43-70.

CANNIZZARO, T. - "In morte di Anthero de Quental", in Tramonti. Messina. Tipi del'autore, 1892. p. 203-207.

CANTO, Ernesto do - "À memória de Antero de Quental", Arquivo dos Açores, 12, Ponta Delgada 1892-1894. p. 161-247.

- "O brazão dos Quentais", in Anthero de Quental. In Memoriam. Porto, Mathieu Lugan Editor, 1896. p. 527.

CAPELA, Raimundo - "Antero de Quental", Gazeta de Notícias, Rio de Janeiro, 30 Set. 1891.

- "Memórias de Antero de Quental (fragmento)", Nova Alvorada,

$\mathrm{n}^{\circ} 7$, Vila Nova de Famalicão, 1 Nov. 1891. p. 76-77.

CARNEIRO, Roberto - "Antero: o universal-insular", JL-Jornal de Letras, Artes e Ideias, $\mathrm{n}^{\circ}$ 479, Lisboa, 10 Set. 1991. p. 9.

CARPEAUX, Otto Maria - "Antero de Quental e o pensamento alemão", Atlântico-Revista Luso-Brasileira, 3, Rio de Janeiro, 1943. p. 38-41.

CARREGAL, J. da Costa - Notícia para a bibliografia antheriana. Porto, Grémio Nacional dos Industriais de Tipografia, 1942. 106 p. il.

CARREIRO, Carlos - Leonardo e o seu culto por Antero. Ponta Delgada, Ed. D.A., s.d. 19 p.

CARREIRO, José Bruno - Anteriana. s.l., s.n., s.d.. 20 fls dactilografadas.

- "Antero de Quental", in Albino Forjaz de Sampaio (Dir.)

História da literatura portuguesa ilustrada dos séculos XIX $e X X$. Porto, Livraria Fernando Machado, 1942. Vol. IV. p. 150-172.

- Antero de Quental: notas sôbre a sua vida. Ponta Delgada, Gráfica Regional, 1934. 48 p.

- Antero de Quental: subsídios para a sua biografia. Ponta

Delgada, Instituto Cultural de Ponta Delgada, 1948. 2 vols.

- Antero de Quental. Subsídios para a sua biografia. $2^{\mathrm{a}}$ ed.. Ponta

Delgada, Instituto Cultural de Ponta Delgada, 1981. 2 vols.

- A cronologia dos "Sonetos" de Antero de Quental. Ponta Delgada, 1944.

- "As mulheres de Antero", Seara Nova, 406-408, Lisboa, 1934.

p. 339-344.

- "Os últimos dias de Antero", Novidades - Supl. "Artes e Letras",

Lisboa, 19 Abr. 1942. p. 2-3. 
CARRILHO, António Louro - Antero de Quental e o socialismo. Subsídios para a compreensão do seu pensamento político. Évora, s.n., 1985.55 p.

"Cartas inéditas reabrem polémica sobre Antero", Diário de Notícias, Supl. "Cultura", Lisboa, 11 Nov. 1982. p. 15-16.

CARVALHAL, Álvaro do-Anthero de Quental e Ramalho Ortigão. Coimbra, Imprensa da Universidade, 1866. 15 p.

CARVALHO, Amorim de - "O centenário de Antero de Quental", Portucale, 15(86-87), Porto, 1942. p. 110.

CARVAlHO, Cristiano de - "Antero de Quental", Pensamento, Porto, ano 7, vol. 5, n. ${ }^{\circ} 78,1936$. p. 6.

- Revelações. A sociedade portuguesa de então. A nação e as classes... Antero de Quental e a Liga Patriótica do Norte. Barcelos, Portucalense Editora, 1932. p. 72-74.

CARVALHO, Joaquim de - Acerca dos Raios de extinta luz. Lisboa, 1944.

- "Antero", Academico Figueirense, Ano 2, n. ${ }^{\circ} 7,2^{\mathrm{a}}$ série, Figueira da Foz, 27 Abr. 1935. p. 1.

- Antero de Quental e a filosofia de Eduardo Hartmann, Sep. de

In Memorian de Delfim Guimarães. Lisboa, Imprensa Lucas, 1934.

$27 \mathrm{p}$.

- "Centenário de Antero de Quental", Biblos, 18(1), Coimbra, 1942. p. 267-272.

- "Comemoração de Antero de Quental: Antero de Quental. As suas concepções de vida", Revista de Guimarães, Guimarães, 52 (3-4), 1942. p.276-288.

- Estudos sobre a cultura portuguesa do século XIX - Antheriana. Coimbra, Universidade, 1955. 321 p.

- A evolução espiritual de Antero: Ensaio breve de interpretação. Lisboa, Seara Nova, 1929. 109 p.

- Evolução espiritual de Antero e outros escritos. Angra do Heroísmo, Secretaria Regional de Educação e Cultura, 1983. 235 p. - "Formação da ideologia republicana (1820-1880)", in Montalvor, Luís de, Historia do Regímen Republicano em Portugal. Vol.

1. Lisboa, Ed. Ática, 1930-1932. p. 163-256.

- "Morte e imanência no pensamento de Antero de Quental", Revista Filosófica, 10, Coimbra, 1954. p. 71-82.

- Sobre a origem da concepção da inconsciência de Deus em 
Antero de Quental. Coimbra, Universidade, 1944. p. 131-141.

- "As três vidas de Antero", Biblos, 18(2), Coimbra, 1942. p. 576-578 .

CARVALHO, Manuel Herculano de - "Páginas que ficaram por escrever em 'Antero e Beethoven'", Estudos, 10(212), Coimbra, 1942. p. 485-491.

CARVAlHO, Maria Amália Vaz de - "Antero de Quental", in Alguns homens do meu tempo. Lisboa, Typ. de Christovão Augusto Rodrigues, 1889. p. 105-163.

- "Anthero de Quental. A sua obra e a sua morte", in Pelo mundo fora. Lisboa, Liv. António Maria Pereira, 1896. p. 171-194.

CARVALHO, Ruy Galvão de - $O$ açorianismo de Antero de Quental. Coimbra, Coimbra Editora, 1984. 13+2 p.

- Algumas notas sobre Antero de Quental. Um aspecto da sua psicologia. Coimbra, Ed. do Autor, 1928.46 p. Tese de licenciatura dactilografada.

- "Antero", Diário de Coimbra, Coimbra, 16 Abr. 1942. p. 1.

_ "Antero de Quental", Revista de História das Ideias, 13, Coimbra, 1991. p. 387-399.

- "Antero de Quental e António Sardinha profetas do perigo eslavo", Panorama, 20, 3ª série, Lisboa, 1960. p. 11-15.

- "Antero de Quental na fase última da sua vida", in Três ensaios sôbre Antero de Quental, Coimbra, Imprensa da Universidade, 1933. p. 87-110.

- "Antero o maior de todos", Boletim da Academia Portuguesa de Ex-Libris, 10(33), Lisboa, Jul.1965. p. 158-166.

- "Antero de Quental mestre da contra-revolução", A Voz, Supl. "Bazar das Letras, das Ciências e das Artes", série VI, nº 43, Lisboa, 17 Abr. 1942. p. 196.

- Antero de Quental e a mulher. Ensaio breve de interpretação psicológico-literária. Lisboa, Ed. de Álvaro Pinto ('Ocidente'), 1949. $55 \mathrm{p}$.

- Antero de Quental e a música. Horta, Direcção Regional dos Assuntos Culturais/Centro de Estudos e Cultura da Câmara Municipal da Horta, 1989. 133 p.

- "Antero de Quental nas 'Odes Modernas'", Ocidente, 29(97),

Lisboa, 1946. p. 9-24.

- "Antero de Quental nos 'Raios de extinta luz"', Ocidente, 
26(86), Lisboa, 1945. p. 80-96 il.

- "Antero de Quental nos 'Sonetos completos'", Ocidente, 17(50),

Lisboa, 1942. p. 162-177 il.

- Antero de Quental. Novos ensaios. São Miguel, Ed. Ilha Nova,

1985. $189+22 \mathrm{p}$.

- Antero vivo: ensaios. Lisboa, Ed. Álvaro Pinto, 1950. 193 p.

- Camões e Antero. Braga, s.n., 1980. 7 p.

- "Cartas inéditas de Antero de Quental no espólio literário de

Joaquim de Araújo", Ocidente, 61(284), Lisboa, 1961. p. 265-270. - Colectanea de estudos anterianos. Angra do Heroísmo, Secre-

taria Regional de Educação e Cultura, 1979. 202+1 p.

- "O culto da coerência em Antero de Quental", Gil Vicente, 7(5-

-6), Guimarães, 1956. p. 72-75.

- "O génio poético de Antero", in Três ensaios sôbre Antero de

Quental. Coimbra, Imprensa da Universidade, 1933. p. 23-33

- "O génio poético de Antero", Brotéria, 81(3), Lisboa, 1965. p.

173-180.

- "Inauguração na Universidade da Sala Antero de Quental", Arquipélago, Série Línguas e Literaturas, 9, Ponta Delgada, 1987.

p. $169-173$.

- "A inquietude religiosa de Antero", in Três ensaios sôbre

Antero de Quental, Coimbra, Imprensa da Universidade, 1933. p.

35-86.

- "Meditação sobre a vida de Antero", Biblos, 56, Coimbra, 1980.

p. 349-356.

- "A mulher na lírica de Antero", Insulana, 13, Ponta Delgada, 1957. p. 65-88.

_- "O narcisismo de Antero", Gil Vicente, 12(9-10), Guimarães, 1936.

- "Nota breve sobre a timidez de Antero", Portucale, 6, Porto, 1933. p. 192-197.

- Notas sobre Antero de Quental. Suas tendências filosóficas.

Ponta Delgada, Of. Diário dos Açores, 1928. 47 p.

- Ordenação cronológica dos "Sonetos Completos" de Antero

de Quental. Angra do Heroísmo, União Gráfica Angrense, 1962.

$23 \mathrm{p}$.

- "Pela seara alheia - Antero vivo", Ocidente, 41(163), Lisboa, 1951.p. 205. 


\section{Elementos para uma bibliografia}

- "Poesia e música açoriana", Ocidente, 41(163), Lisboa, 1951.

p. $165-188$.

- "Presença espiritual da França na obra de Antero", Afinidades,

12, Lisboa, 1945. p. 30-35.

- "A presença da morte nos Sonetos de Antero", Ocidente, 18(53),

Lisboa, 1942. p. 29-31.

- "A propósito da Antheriana do Prof. Joaquim de Carvalho", Ocidente, 49(210), Lisboa, 1955. p. 152-154.

- "As raízes bocageanas dos 'Sonetos completos' de Antero de Quental", Gil Vicente, $2^{\mathrm{a}}$ série, 17(11-12), Guimarães, Nov-Dez. 1966. p. 169-172.

- "A 'Serenata' de Antero", Ocidente, 69(330), Lisboa, 1965. p. 156-157.

- "Sobre Antero", Correio dos Açores, Ponta Delgada, 20 Abr. 1941.p. 3.

- "OSonetoé também voz açoriana", Ocidente, 37, Lisboa, 1949. p. 273.

- Três ensaios sobre Antero de Quental. Coimbra, Imprensa da Universidade, 1933. $172 \mathrm{p}$.

- "Uma carta inédita de Antero de Quental", Colóquio, 14, Lisboa, 1961. p. 53-54.

- "A vida de Antero", A Voz, Supl. "Bazar das Letras, das Ciências e das Artes", série VI, nº 43, Lisboa, 17 Abr. 1942. p. 195.

CARVALHO, Sebastião de - "Registo bibliographico. Anthero de Quental en efterskord ofversattninger af Goran Bjorkman", Nova Alvorada, $5^{\circ}$ anno, $\mathrm{n}^{\circ}$ 6, Vila Nova de Famalicão, Set. 1895. p. 48. CASTELO BRANCO, António de Azevedo - "À memória de Antero", in Meridionais, Lisboa, Livraria Editora Guimarães, 1925. p. 29.

- "Anthero de Quental", Nova Alvorada, $6^{\circ}$ Anno, $\mathrm{n}^{\circ}$ 11, Vila Nova de Famalicão, Fev. 1897. p. 180-181.

CASTELO BRANCO, Camilo - Vaidades irritadas e irritantes. Opusculo àcerca d'uns que se dizem offendidos em sua liberdade de consciencia litteraria. Porto, Em casa de Viúva Moré, 1866. 47 p.

CASTELÕES, Álvaro- " Anthero de Quental", Nova Alvorada, Vila Nova de Famalicão, Ano 1, n. ${ }^{\circ} 7$, Nov. 1891. p. 76.

CASTILHO, Guilherme de - "Antero de Quental. Reflexões de metodologia literária", Atlântico, 1, Ponta Delgada, 1942. p. 137- 
-140 .

CASTILHO, Júlio de - O Senhor António Feliciano de Castilho e o senhor Antero de Quental. Lisboa, Imprensa de J. G. de Sousa Neves, $1865.40 \mathrm{p}$.

CASTILHO-ELEPABEYTIA, Dictino - A Antero, en los saudosos campos. Ponta Delgada, Tip. Diário dos Açores, 1953. 7 p.

CASTRO, Eugénio V. P. do Canto e - "Discurso commemorativo", in Anthero de Quental. In Memoriam. Porto, Mathieu Lugan, Ed., 1896. p. 337-348.

CASTRO, Ferreira de - "O monumento a Antero de Quental", $A B C$, Ano 5, n 210, Lisboa, 24 Jul. 1924. p. (3).

CASTRO, Sérgio de - "O amor na obra de Antero: uma crónica inédita", Diário Popular, Lisboa, 11 Set. 1943. p. 4.

CASULO, José Carlos - "O pensamento educacional de Antero". Revista Portuguesa de Filosofia, 47(2), Braga, 1991. p. 281-292.

Catálogo da exposição anteriana, realizada na sede de $A$ Voz do Operário. Lisboa, A Voz do Operário, 1942. 35 p.

Catálogo da Livraria de Anthero de Quental, legada á Bibliotheca Publica de Ponta Delgada. Ponta Delgada, s.n., (de 1899). 158 p. il.

Catálogo da livraria de Antero de Quental. Prol. de Gustavo de Fraga. Ponta Delgada, Biblioteca Pública e Arquivo, 1991. 222 p.

CATROGA, Fernando - "A ciência e a metafísica na filosofia de Antero", in Filosofia, História e Conhecimento. Homenagem a Vitorino Magalhães - Vilhena. Lisboa, Editorial Caminho, 1990. p. 223-234.

- "Ética e sociocracia. O exemplo de Herculano na geração de 70", Studium Generale. Estudos Contemporâneos, 4, Porto, 1982. p. 9-63.

- "Filosofia e sociologia - A ideia anteriana de socialismo", Vértice, 42, Coimbra, 1982. p. 294-317.

- "A ideia de evolução em Antero de Quental", Biblos, 56, Coimbra, 1980. p. 357-388.

- "Os inícios do positivismo em Portugal", Revista de História das Ideias, 1, Coimbra, 1977. p. 287-293.

- "A metafísica indutiva de Antero de Quental", Biblos, 61, Coimbra, 1985. p. 472-507.

- "O optimismo transcendental", JL - Jornal de Letras, Artes e 
Ideias, $\mathrm{n}^{\circ} 466$, Lisboa, 11 Jun. 1991. p. 12-13. - "Política, História e Revolução em Antero de Quental", Revista de. Histórias das Ideias, 13, Coimbra, 1991. p. 7-55. - "Oproblema políticoem Antero de Quental - um confronto com Oliveira Martins", Revista de História das Ideias, 3, Coimbra, 1981. p. 341-520.

CAVALHEIRO, Rodrigues - "As antevisões de Antero", in Homens e. Ideias. Lisboa, Livraria Sam Carlos, 1960. p. 191-200. - "Sob a invocação de Clio. Falemos de Antero", Ocidente, 37, Lisboa, 1949. p. 144-148.

CEBOLA, Luís - Patografia de Antero de Quental. Lisboa, s.n., $1955.113 \mathrm{p}$.

CELLINI, C. - "Sul Tumulo", Nova Alvorada, Anno 1, n 7, Vila Nova de Famalicão, 1 Nov. 1891. p. 63.

"Centenário de Antero: congressos, colóquios e outras iniciativas", JLJornal de Letras, Artes e. Ideias, Ano XI, nº 466, Lisboa, 11 Jun. 1991.p. 22.

CHAGAS, Manuel Pinheiro - Bont-senso e bom gosto: folhetim a propósito da carta que o senhor Antero de Quental dirigiu ao senhor António Feliciano de Castilho. Lisboa, Imprensa de J. G. de Sousa Neves, 1965. 12 p.

CHAVES, Castelo-Branco - "Antero de Quental e Fernando Pessoa", Estudos, 31(314), Coimbra, 1953. p. 87-93.

- "Marginália sobre a actividade de Antero", Pensamento, Porto, Ano 7, vol. 5, n. ${ }^{\circ} 78,1936$. p. 9.

- "A mulher e o sentimento do amor em Antero de Quental", Nação Portuguesa, 5, 2a série, 1922. p. 206-210.

_- "Os Vencidos da Vida", Seara Nova, 14, Lisboa, 1931. p. 219.

CHAVES, Luís - "O mar em Antero", Novidades - Supl. "Artes e Letras", Lisboa, 19 Abr. 1942. p. 1-2.

CIDADE, Hernâni - "Antero de Quental", in Os grandes portugueses. vol. 2. s.l., Editora Arcádia, s.d.. p. 385-392.

- Antero de Quental. Lisboa, Arcádia Editora, 1962. 231 p.

- Antero de Quental. $2^{\mathrm{a}}$ ed. Lisboa, Presença 1988. 155 p.

- Antero de Quental. A obra e o homem. $2^{\mathrm{a}}$ ed.. Lisboa, Arcádia Editora, 1978. 157 p. il.

- Antero de Quental. A obra e o homem. $3^{\mathrm{a}}$ ed.. Lisboa, Arcádia Editora, s.d.. 157 p. 
- "Antero poeta", Biblos, 18, Coimbra, 1942. p. 273-276.

- "Antero de Quental poeta", Revista da Faculdade de Letras de Lisboa, 8, Lisboa, 1942. p. 24-44.

- "O conceito de poesia de Antero e sua geração", in $O$ conceito da poesia como expressão da cultura. Coimbra, Arménio Amado, Ed., 1945. p. 227-238.

- "A intervenção de Antero na vida pública", Seara Nova, 406-408, Lisboa, 1934. p. 356-358.

- "Quental, Antero Tarquínio de", in Dicionário de Literatura. Dir. Jacinto do Prado Coelho. Porto, Figueirinhas, 1978. p. 891$-894$.

- "Santo Antero", in Século XIX. A revolução cultural em Portugal e alguns dos seus mestres. Lisboa, Ática, 1961. p. 173-189.

- "O significado do lirismo de Antero", Pensamento, Porto, Ano 7, vol. 5, n. 78,1936 . p. 10.

COELHO, F. Adolfo - "A constituição poética de Anthero de Quental", in Anthero de Quental. In Memoriam. Porto, Mathieu Lugan, Ed., 1896. p. 37-51.

- "O supposto escandinavismo de Anthero de Quental", Revista de Ciências Naturaes e Sociaes, 5, Porto, 1898. p. 57-121.

COELHO, Jacinto do Prado - "As ideias e as formas. A questão Coimbrã", Ocidente, 31, Lisboa, 1947. p. 153-163.

COELHO, João - "Coisas da nossa terra. Antero de Quental na Figueira", Album Figueirense, Ano 1, n. ${ }^{\circ}$, Figueira da Foz, Jun. 1934. p. 4-8.

COELHO, Joaquim Francisco - "Oftalmografias de Antero", JL-Jornal de Letras, Artes e Ideias, Ano XI, n 466, Lisboa, 11 Jun. 1991.p. 9.

COELHO, Nelly Novaes - "O mundo poético anteriano", Alfa, 7-8, Marília, 1965. p. 61-88.

COIMBRA, Leonardo - "Antero de Quental e a crise contemporânea", Mocidade, ano V, $2^{\mathrm{a}}$ série, 18 Abr. 1929.

- O pensamento filosófico de Antero de Quental. Porto, J. Pereira da Silva, s.d.. 269 p.

- O pensamento filosófico de Antero de Quental. $2^{\mathrm{a}}$ ed.. Porto, 1944.

- O pensamento filosófico de Antero de Quental. Apres., fixação do texto e notas de Paulo Samuel. Lisboa, Guimarães Editores, 


\section{Elementos para uma bibliografia}

1991. $170 \mathrm{p}$.

"Comemoração de Antero (Conferência)", Revista de Guimarães, 52(3-4), Guimarães, 1942. p. 276-288.

"Comemorações anterianas", Letras e Letras, $\mathrm{n}^{\circ}$ 43, Porto, 20 Mar. 1991.p. 17.

"Comemorações do $1^{\circ}$ centenário do nascimento de Antero de Quental, realizadas pela Academia de Coimbra", Via Latina, 10, Coimbra, 30 Abr. 1942. p. 1-16.

CORREIA, Morão - Antero de Quental. Breves considerações sobre a sua obra. Luanda, Câmara Municipal de Luanda, 1972. 22 p.

CORREIA, Natália - "Espreitar o mistério", JL- Jornal de Letras, Artes e Ideias, Ano XI, nº 466, Lisboa, 11 Jun. 1991. p. 19.

CORTESÃO, Jaime - A arte e a medicina. Antero de Quental e Sousa Martinz. Coimbra, Tip. França Amado, 1910. 178 p.

- "Remorso pela morte de Antero", Seara Nova, 847, Lisboa, 1943. p. 167-170.

COSTA, Joaquim - "Antero de Quental", in Recordar é viver. Porto, Lello \& Irmão, 1924. p. 175-180.

- "Antero de Quental", in A expressão literária e a aprendizagem

do estilo. Porto, Livraria Chardron \& Lello, Ld Ld $^{2}$ 1928. p. 297-298.

- "Duas inquietações: Antero de Quental e Amiel", Ocidente, 14(39), Lisboa, 1941. p. 5-20.

COSTA, JoãoSá da - "Garrette Antero", Vértice, 14, Coimbra, 1954. p. 685-687.

COSTA, Júlio Dias da - "Notas às Odes Modernas de Antero de Quental", in Escritos de Camilo. Lisboa, Portugália, 1923. p. 118-140 .

COSTA, Sebastião (Sob pseud. de J. Reinol) - "Antero de Quental e o povo", Correio dos Açores, Ponta Delgada, 20 Abr. 1941. p. 1 e 3.

COXITO, Amândio Augusto - "Antero, Vacherot e o espiritualismo francês do séc. XIX. O tema da liberdade", Revista de. História das Ideias, 13, Coimbra, 1991. p. 57-72.

CRESPO, Firmino - "Reflexos micaelenses na personalidade de Antero de Quental", Ocidente, $\mathrm{N}^{\circ}$ especial, Lisboa, 1987. p. 32-39.

CRUZ, António - "A humanidade de Antero", Diário de Coimbra, Coimbra, 26 Abr. 1942. p. 1-2.

CUNHA, Elmano da - Bom-senso-bom-gosto: carta em resposta a 
outra dirigida por Antero de Quental ao excelentíssimo senhor António Feliciano de Castilho.... Coimbra, Imprensa da Universidade, $1865.15 \mathrm{p}$.

CUNHA, Norberto - "Ciência, cientismo e metaciência em Antero", Revista Portuguesa de Filosofia, 47(2), 1991. p. 325-348.

DANTAS, Júlio - "Antero", Via Latina, 10, Coimbra, 30 Abr. 1942. p. 1.

- "O centenário de Antero de Quental. Discurso pronunciado em sessão solene da Academia das Ciências na noite de 18 de Abril de 1942", in Discursos. Lisboa, Livraria Bertrand, s.d.. p. 139-156.

- "Opinióes sobre Antero de Quental: o drama de Antero", $A$ Ilha, Ponta Delgada, 19 Abr. 1941. p. 6, 9.

- "A poesia de Antero", O Primeiro de Janeiro, Porto, 19 Abr. 1942. p. 1.

DELILLE, Maria Manuela Gouveia - "Antero e a geração de Coimbra", in A recepção literária de $H$. Heine no romantismo português de 1844 a 1871. Lisboa, Imprensa Nacional-Casa da Moeda, 1984. p. 161-255.

- "A lírica portuguesa moderna: de 1865 a 1890", Colóquio Letras, 53, Lisboa, 1980. p. 67-70.

DEUS, João de - "Anthero de Quental", Arte, Revista Internacional, 1, Coimbra, 1895-1896. p. 10.

- "No tumulo de Anthero", in Anthero de Quental. In Memoriam. Porto, Mathieu Lugan, Ed., 1896. p. 529.

DEUSDADO, M. A. Ferreira - "Antero de Quental", in Educadores Portugueses. Angra, Minerva Cunha, 1909. p. 470-476.

DIAS, Augusto Malheiro - Castilho e Quental. Porto, Liv. Francisco Gomes da Fonseca, 1866. 20 p.

DIAS, Urbano de Mendonça - "Antero de Quental", in Literatos dos Açores. Vila Franca do Campo, Empresa Tipográfica, 1931.p. 235$-261$.

DIMUNNO, Amina - "Antero de Quental perante a Itália: Alegoria de Beatrice em Dante e na poesia anteriana", Letras e Letras, ano 5, $\mathrm{n}^{\circ}$ 59, Porto, 20 Nov. 1991. p. 9-10.

DIONÍSIO, Guilherme Santana - "Aparas de um estudo feito sobre Antero", Pensamento, Porto, Ano 7, vol. 5, n. ${ }^{\circ} 78,1936$. p. 20-23. DIONíSIO, José Augusto Santana - Antero: algumas nôtas sobre o seu drama e a sua cultura. Lisboa, Seara Nova, 1934. 228 p. 
- "Considerações genéricas sobre os riscos da análise discursiva do espírito. A propósito da dificuldade de integração das diferentes 'personalidades' de Antero", Seara Nova, 387, Lisboa, 1934. p. 35$-39$.

- "Contra o pensamento de Antero sôbre a origem e o fim da música", Seara Nova, 539, Lisboa, 1937. p. 247-249.

- "As doenças de Antero", Seara Nova, 373, Lisboa, 1934. p. 201$-207$.

- "Do optimismo de Antero", Seara Nova, 383, Lisboa, 1934. p. 356-359.

- "O enigma da morte de Antero", Seara Nova, 395, Lisboa, 1934.

p. 166-168.

- "Inquirição do que há de 'humoral' e de 'reflexivo', nos 'Sonetos' de Antero", Seara Nova, 388, Lisboa, 1934. p. 53-58.

- "Luta pela inteligibilidade. O progresso intelectual de Antero durante os últimos dez anos da sua vida", Seara Nova, Lisboa, 1934, 392, p. 115-119 e 394, p. 153-154.

- "Recônditos sofrimentos do poeta Antero de Quental", $O$ Primeiro de Janeiro -Supl. "Das Artes, Das Letras", 13 Jan. 1982. p. 20.

- A sinceridade politica de Antero de Quental. Porto, Imprensa Portuguesa, 1949. $80 \mathrm{p}$.

- "Tentativa de definição do que talvez seja permitido chamar o fracasso de Antero", Seara Nova, 733-734, Lisboa, 1941. p. 259$-262 ; 281-284$.

DÓRIA, António Álvaro-Ainda a Geração de 70. Braga, s.n., 1975. $16 \mathrm{p}$.

- Antero de Quental em Vila do Conde. Braga, s.n., 1982. 55 p. - Antero vivo. Braga, Ed. Bracara Augusta, 1951. 15 p.

DURÃO, Américo - "Opiniões sobre Antero de Quental. A musa de Antero", A Ilha, Ponta Delgada, 19 Abr. 1941.p. 6, 10.

ENES, Maria Fernanda - "O discurso anteriano e a questão laica na 'Quanta Cura' de Pio IX", Revista de História das Ideias, 13, Coimbra, 1991. p. 361-377.

"O estatuário Teixeira Lopes e o monumento a Antero de Quental em Ponta Delgada", Ocidente, 18(55), Lisboa, 1942. p. 297-302.

"Faz hoje cem anos que nasceu Antero de Quental", Novidades, Lisboa, 18 Abr. 1942.p. 1 e 4. 
FÉRES, Nites - Antero. Assis, Faculdade de Filosofia, Ciências e Letras de Assis, 1961. $24 \mathrm{p}$.

FÉRIN, Madalena - "Antero de Quental - o poeta da encruzilhada", Ocidente, $\mathrm{N}^{\circ}$ especial, Lisboa, 1982. p. 20-22.

FERNANDES, Vasco da Gama - "Antero: motivo eterno", Vida Contemporânea, 2, Lisboa, 1934. p. 255-259.

FERNANDEZ ALONSO, Maria del Rosario - "El 'ciclo da morte' de Antero de Quental", in Una vision de la muerte en la lirica española. La muerte como amada. Madrid, Editorial Gredos, 1971. p. 411-421.

FERRÃO, Carlos - "Antero e os Vencidos", $A B C$, Ano 1, $\mathrm{n}^{\circ} 35$, Lisboa, 10 Mar. 1921. p. (12-13).

FERREIRA, A. A. da Costa - "Sobre uma carta de Antero de Quental", Revista de História, 3, Lisboa, 1914. p. 250-251.

FERREIRA, Alberto - "Antero de Quental e a reforma moral", in Estudos de cultura portuguesa - Século XIX. Lisboa, Morais Editores, 1980. p. 135-142.

- Bom senso e bom gosto. Questão Coimbrã. Recolha, notas e bibliografia de Maria José Marinho. Lisboa, Portugália Editora, 1966-1970. 4 vols.

- e MARINHO, Maria José - Antologia de textos da "Questão Coimbrã". Lisboa, Moraes Editora, 1980. 273 p.

FERREIRA, David Mourão - "Larbaud, Pessoa, Antero: note sur une rencontre", Ariane. Revue d'Études Littéraires Françaises, 1, Lisboa, 1982. p. 203-206.

- "Larbaud, Pessoa, Antero. O recurso à ode como forma de modernidade", in Colloque Les rapports culturels et littéraires entre le Portugal et la France. Paris, Centre Culturel Portugais-Fondation Calouste Gulbenkian, 1983. p. 559-569.

FERREIRA, Noémia da Luz - "Antero de Quental. Conferência", in João H. Anglin, $O$ Liceu de Ponta Delgada e a sua acção cultural nos anos de 1926 a 1936. Ponta Delgada, Papelaria Ambar, 1936. p. 5-13.

FERREIRA, Vítor Vladimiro - "As raízes açorianas", Diário de Notícias, "Caderno 2: Antero de Quental, O príncipe da agonia", Lisboa, 12 Maio 1991. p. 6-7.

"Festejando uma data", Diário de Coimbra, Coimbra, 17 Abr. 1942.p. 1-2; 19 Abr. 1942. p. 1-2. 


\section{Elementos para uma bibliografia}

FIGUEIREDO, Cândido de - "Anthero de Quental", in Homens $e$ Letras. Lisboa, Typ. Universal, 1881. p. 161-168; 307-309.

FIGUEIREDO, Fidelino de - Antero. São Paulo, Departamento Municipal de Cultura, 1942. 224 p. il.

- "Antero em perspectiva", in Estudos de Literatura. São Paulo, Universidade de São Paulo,1951.p.11-36.

- "Antero de Quental", in A crítica literária como ciência. $3^{\mathrm{a}} \mathrm{ed}$.

Lisboa, Liv. Clássica Editora de A. M. Teixeira, 1920. p. 249-251. - "Antero de Quental", in História da literatura realista. Lisboa,

Livraria Clássica Editora, 1924. p. 39-85. - Antero de Quental. A sua psicologia, a sua filosofia e a sua arte.

Lisboa, Typ. da Cooperativa Militar, 1909. 16 p. - Os melhores sonetos da língua portuguesa. Lisboa, Livraria Central, 1907. p. 61-82.

- "Opiniões sobre Antero de Quental: a bondade de Antero", $A$ Ilha, Ponta Delgada, 19 Abr. 1941. p. 6, 10.

FLORES, Francisco Moita - "Agora e na hora da morte de Antero", Letras e Letras, Ano V, no 59, Porto, 20 Nov. 1991. p. 13-14. - "As mortes de Antero de Quental - 'Autópsia' de um suicídio", Revista de História das Ideias, 13, Coimbra, 1991. p. 283-359.

FONSECA, F. Guimarães - "Antero de Quental", Diário Ilustrado, Lisboa, 24 Set. 1875.

FONSECA JÚNIOR, João Augusto - "Uma atitude de Antero. Coordenação duns apontamentos duma obra a realizar", $O$ Instituto, 70, Coimbra, 1923. p. 241-254; 368-382; 409-429.

FORMONT, Maxime - "Antero de Quental", Nova Alvorada, Anno 1, $\mathrm{n}^{\circ} 7$, Vila Nova de Famalicão, 1 Nov. 1891. p. 62.

- Le mouvement poétique contemporain en Portugal. Lyon, Imprimerie A. Storck, 1892. p. 6-13.

FRAGA, Clementino - "Sob o signo de Antero", Revista do Arquivo Municipal, 8(88), São Paulo, 1943. p. 173-180.

FRAGA, Gustavo de - "Antero e o federalismo peninsular", Revista Portuguesa de Filosofia, 47(2), Braga, 1991. p. 227-245. - "José Bruno Carreiro. O anterista", Arquipélago. Série Ciências Humanas, 4, Ponta Delgada, Jan. 1982. p. 65-93.

- "Prólogo", in Catálogo da Livraria de Antero de Quental,

Ponta Delgada B. P. A. P. D., 1991. p. 13-24.

- "Reflexão sobre Antero", Arquipélago. Série Ciências Hu- 
manas, 1, Ponta Delgada, 1979. p. 9-41.

FRANÇA, José-Augusto - "As angústias de Antero de Quental", in O Romantismo em Portugal. Lisboa, Livros Horizonte, 1975. p. 1035-1065.

- (apresent. e notas) As Conferências do Casino no Parlamento. Lisboa, Livros Horizonte, 1973. 198 p.

FRANÇA, Nobre - "Antero de Quental", O Protesto Operário, Lisboa, 27 Set. 1891.

- "Anthero de Quental", Nova Alvorada, Anno 2, n 4, Vila Nova de Famalicão, 1 Jul. 1892. p. 142.

FRANCISCO, José - Os Coimbrões: questão em que também entra pelos cem réis. Porto, Tip. de Manuel José Pereira, 1866. 15 p.

FREITAS, Maria da Conceição Machado de - "Antero de Quental. O drama da sua morte", Correio dos Açores, Ponta Delgada, 11 Set. 1923. p. 1-2.

FREITAS, Maria Helena de - "Antero de Quental e a música", Diário de Notícias,5 Jul. 1956. p. 7-8.

FURLAN, Francisco A. - "Antero de Quental diante do confronto: realidade portuguesa e modernidade", Estudos Portugueses e Africanos, 15, Campinas, 1990. p. 93-104.

- "Comentários acerca do livro dos sonetos de Antero de Quental", Estudos Portugueses e Africanos, 9, Campinas, 1987. p. 43$-76$.

GAIO, Manuel da Silva - "Antero Filósofo", Correio dos Açores, Ponta Delgada, 10 Set. 1922. p. 2.

- Os vencidos da vida. Coimbra, Imprensa da Universidade, $1931.61 \mathrm{p}$.

GALA, José Luís Vaz e - "A Liga Patriótica do Norte e a sua repercussão em Lisboa. Propósitos e fontes de um trabalho", Boletim da Biblioteca Pública Municipal de Matosinhos, 32, Matosinhos, 1988. p. 29-106.

GARCEZ, Maria Helena Nery - "Fernando Pessoa e Antero de Quental", in Trilhas em Fernando Pessoa e Mário de Sá-Carneiro. São Paulo, Moraes/EDU SP, 1989.

GARCÍA MOREJÓN, Julio - "Unamuno y el sentimento tragico de Antero de Quental", Cuadernos de la Catedra Miguel Unamuno, 11, Salamanca, 1961. p. 27-65.

GARCIA, Maria da Graça - $O$ antipositivismo e Antero de Quental. 


\section{Elementos para uma bibliografia}

Coimbra, Ed. do Autor, 1959. 66 p. Tese de licenciatura dactilografada.

GARCIA, Mário - "Os Sonetos Completos de Antero de Quental, 100 anos depois", Brotéria, 126(6), Lisboa, Nov. 1986. p. 564-566.

Garrett, Castilho, Herculano e a escola coimbrã ou dissertação ácerca da genealogia da moderna escola contendo um esboço rápido e pitoresco da litteratura contemporânea, pelo Ermita do Chiado. Lisboa, Imprensa de J. G. de Sousa Neves, 1866. 15 p.

GAVETA, Amaro Mendes - O mau senso e o mau gosto: carta mui respeitosa ao excelentíssimo senhor António Feliciano de Castilho em que se fala de todos e de muitas pessoas mais. Lisboa, Imprensa de J. G. de Sousa Neves, 1866. 16 p.

GERALDES, Dulce Barbosa de - Actualidade do pensamento em Antero de Quental. Coimbra, Ed. do Autor, 1973. V+201 p. Tese de licenciatura policopiada.

GILLESPIE, John C. - "Eça, Antero e a Geração de 70", Ocidente, 75(368), Lisboa, 1968. p. 213-216.

GOMES, Delfim - Bibliographia antheriana. Defesa d'algumas notas impugnadas pelo sr. Joaquim de Araújo. Coimbra, s.n., 1896. $24 \mathrm{p}$.

- Bibliografia anteriana. Notas ao ensaio do sr. Joaquim de. Araújo. Coimbra, s.n., 1896. 24 p.

- "Primicias de Anthero de Quental (prosa e verso)", Nova Alvorada, Anno 3, $\mathrm{n}^{\circ}$ 6, Vila Nova de Famalicão, 1 Set. 1893. p. 45.

GUEDES, Marques - "A doença de Antero", O Primeiro de Janeiro, Lisboa, 15 Set. 1933. p. 1.

La génération de 70: époque, chefs de file, relations avec la France. Exposition bibliographique organisée par le Centre Culturel Portugais de la Fondation Calouste Gulbenkian. Avant-propos de Joaquim Veríssimo Serrão. Paris, Centre Culturel Portugais, 1971. $154 \mathrm{p}$.

GUERRA, Miller - "António Sérgio e 'Os dois Anteros'", Brotéria, 118(3), Lisboa, 1984. p. 306-311.

- Patografia de Antero de Quental. s.1., Sep. da Revista Rumo, Fev. $1963.6 \mathrm{p}$.

GUIMARÃES, Argeu - Antero em Roma. Rio de Janeiro, Livraria J. Leite, 1934. $144 \mathrm{p}$.

GUIMARÃES, Dórdio - Santo Antero: Vida de Antero de Quental. 
Angra do Heroísmo, Secretaria Reginal de Educação e Cultura, s.d. GUIMARÃES, Fernando - " Moral, filosofia e 'poesia do futuro"', $J L$ -Jornal de Letras, Artes e Ideias, n 487, Lisboa, 5 Nov. 1991. p. 19. HOLSTEIN, D. Francisco de Sousa e - "Sonetos de Antero de Quental", in Literatura e história. Lisboa, Esc. Tip. das Oficinas S. José, 1929. p. 64-66.

HORTA, Maria Teresa - "Um mestre do desassossego", Diário de Notícias, Supl. "Caderno 2", Lisboa, 12 Maio 1991.p. 5.

"Inauguração da biblioteca de Anthero de Quental (1 de Janeiro de 1893)", Arquivos dos Açores, 12, Ponta Delgada, 1983. p. 222-227.

IVENS, Diogo - "Hamlet e Antero", Ocidente, 18(53), Lisboa, 1942. p. 5-28.

J, F. H. - "Uma carta de Antero de Quental", Vértice, 10, Coimbra, 1950. p. 313-314.

JARDIM, Luís Ricardo Hintze Ribeiro - Visita do príncipe Humberto de Saboia a Coimbra em Outubro de 1862. Versos de Antero de Quental. Angra do Heroísmo, Instituto Histórico da Ilha Terceira, $1981.9 \mathrm{p}$.

JESUS, Eduíno de - "Breves reflexões sobre Antero de Quental e Baudelaire", Correio dos Açores, Ponta Delgada, 11 Set. 1948. p. 2.

JÚDICE, Nuno - "Antero e Hugo - Diálogo ou conflito?", inVictor Hugo e Portugal. Actas do Colóquio "No Centenário da sua morte". Porto, Faculdade de Letras do Porto, 1985. p. 263-271.

- Antero-Vila do Conde. Lisboa, \& Etc. Imp., 1979. 33 p. il.

- "O duelo da subjectividade", JL-Jornal de Letras, Artes e Ideias, Ano XI, n 466, Lisboa, 11 Jun. 1991. p. 18.

JUNQUEIRO, Guerra - "Anthero de Quental (esboço d'um estudo critico)", Nova Alvorada, Anno 1, n 7, Vila Nova de Famalicão, 1 Nov. 1891. p. 78-79.

- "0 drama da sua vida", in Anthero de Quental. In Memoriam. Porto, Mathieu Lugan, Ed., 1896. p. 473-479.

LASCARIS COMNENO, Constantino-Supuestos filosóficos de Antero de Quental. Madrid, s.n., 1947. 5 p.

LEAL, Fernando (Sob pseud. de Gustavo André) - "Antero de Quental", O Mandarim, 38, 19 Out. 1881.

- "Les sonnets de Quental", in Relâmpagos. Porto, 1888.

LEAL, Gomes - "A filosofia de um deslocado", Nova Alvorada, Ano 


\section{Elementos para uma bibliografia}

I, $\mathrm{n}^{\circ}$ 7, Vila Nova de Famalicão, 1 Nov. 1891. p. 70.

- "Odes Modernas por Antero de Quental", A Democracia, 485,

8 Junho 1875.

LEAL, Raúl- "Antero de Quental chef de l'École", in Contribution à l'étude des idées politiques et sociales de l'École de Coimbre. Paris, Maurice Lavergne, Imp., 1941. p. 35-48.

LEITÃO, Ruben A. - "Antero de Quental. Uma carta inédita a Maria Amália Vaz de Carvalho", Insulana, Ponta Delgada, 5(1), 1949. $7 \mathrm{p}$.

LEMOS, Carlos - "Antherianas", in Miragens. Coimbra, Imprensa da Universidade, 1893. p. 11-74.

"A lição de Antero é a do Homem: (Entrevista com Machado Pires)", JL-Jornal de Letras, Artes e Ideias, ano IX, $\mathrm{n}^{\circ} 388$, Lisboa, 12 Dez. 1989. p. 22.

LIMA, Henrique de Campos Ferreira - "O pai de Antero", Correio dos Açores, Ponta Delgada, 18 Abr. 1937. p. 1.

- "Será Antero a personagem representada num quadro da autoria do Visconde de Meneses?", Vitória, Lisboa, 4 Maio 1946.

LIMA, Jaime de Magalhães - "Antero de Quental", in O amor das nossas coisas e alguns que bem o serviram. Coimbra, Imprensa da Universidade, 1933. p. 169-197.

- "A cultura sistemática do desprendimento e o mistério da morte em Antero", Diário dos Açores, Ponta Delgada, 18 Abr. 1929. p. $1-2$.

- "Um justo", in Anthero de Quental. In Memoriam. Porto, Mathieu Lugan, Ed., 1896. p. 211-218.

- "O pessimismo de Anthero", Diário dos Açores, 10 Set. 1921. p. 1.

LIMA, Sebastião de Magalhães - "Antero de Quental", O Século, Lisboa, 22 Set. 1891. p. 1.

LIMA, Veva de - O único vencido da vida que também ofoi da morte. Lisboa, Silva Lda, 1945. p. 141-145.

LINS, Álvaro - "Centenário de Anthero de Quental", in Jornal de crítica, $2^{\mathrm{a}}$ série. Rio de Janeiro, Livraria José Olympio Editora, 1943. p. 303-312.

- "Poesia e pensamento de Antero de Quental", in $O$ relógio e o quadrante. Rio de Janeiro, Ed. Civilização, 1964.

LOPES, Artur Ribeiro - A inteligência na litteratura nacional. 
Lisboa, Edição do Autor, 1927. p. 55-61.

LOPES, FranciscoFernandes - "Do germanismode Antero", Atlântico, 4, Lisboa, 1943. p. 43-50.

LOPES, Óscar - Antero de Quental. Vida e legado de uma utopia. Lisboa, Editorial Caminho, 1983. 140 p.

- "Meditação desgarrada sobre uma releitura", JL- Jornal de

Letras, Artes e Ideias, Ano XI, n 466, Lisboa, 11 Jun.1991. p. 10-11 .

- "Sobre Antero", in Modo de ler. Porto, Inova, 1969. p. 228-246.

LOUREIRO, Pizarro - Antero de Quental e a inquietação do século $X I X$. Rio de Janeiro, Ed. Inquérito, 1942. 171 p.

LOURENÇO, Eduardo - "Antero ou o socialismo como utopia", in Poesia e Metafísica. Camões, Antero, Pessoa. Lisboa, Sá da Costa, 1983. p. 147-161.

- "Antero ou le socialisme comme utopie", in Actes du Colloque Utopie et Socialisme au Portugal au XIXe siècle. Paris, Centre Culturel Portugais-Fondation Calouste Gulbenkian, 1982. p. 259$-263$.

_- "Antero e a Filosofia", Expresso, Revista, 7 Set. 1991. p. 34R$-36 \mathrm{R}$.

- "Le destin - Antero de Quental. Poésie, révolution, sainteté", in Regards sur la génération portugaise de 1870. Conférences, Paris, Centro Cultural Português, 1971. p. 29-51.

- "Le destin - Antero de Quental", in Poesia e Metafisica. Camões, Antero, Pessoa. Lisboa, Sá da Costa, 1983. p. 119-146.

- "(I)recuperável Antero", JL- Jornal de Letras, Artes e Ideias, Ano XI, n 466, Lisboa, 11 Jun. 1991. p. 8-9.

LUZ, Dinis da - "Antero vive", Correio dos Açores, Ponta Delgada, 11 Nov. 1942. p. 1.

- "A lição de Antero", $A$ Voz, Lisboa, 18 Abr. 1942. p. 1 e 2.

MACEDO, Diogo de - "Antero de Quental e João de Deus", in $O$ festival de João de Deus. Lisboa, Antiga Casa Bertrand - José Bastos, 1905. p. 237-241.

MACHADO, Álvaro Manuel - "Antero: le romantisme total", in Les romantismes au Portugal. Modèles étrangers et orientations nationales. Paris, Fondation Calouste Gulbenkian, 1986. p. 306-369. - "Antero de Quental ou o mestre metafísico", in A geração de 70: uma revolução cultural e literária. Lisboa, Ministério da 


\section{Elementos para uma bibliografia}

Educação e Ciência, 1977. p. 49-58.

- A geração de 70. Uma revolução cultural e literária. Lisboa, Instituto para a Alta Cultura, 1977.91 p.

- "A Geração de 70. Uma Literatura de exílio", Análise Social, $2^{2}$ série, 61-62(16), Lisboa, 1980. p. 383-398.

- $O$ romantismo na poesia portuguesa de Garrett a Antero. Lisboa, ICALP, 1986. 109 p.

MACHADO, Bernardino - Allocução proferida na presidência da sessão solemne celebrada em honra de Anthero de Quental pela Academia de Coimbra, em 20 de Maio de 1899. Coimbra, Imprensa da Universidade, $1899.4 \mathrm{p}$.

- "Anthero de Quental", in A Universidade de Coimbra. Coimbra, Tip. França Amado, 1905.p. 135-141.

MACHADO, Roque - "Antero de Quental. A iconografia antheriana", $A B C$, Ano 7, $\mathrm{n}^{\circ} 327,21$ Out. 1926. p. (16); $\mathrm{n}^{\circ} 328,28$ Out. 1926. p. (8); n 329, 4 Nov. 1926. p. (15); n 330,11 Nov. 1926. p. (7); $\mathrm{n}^{\circ} 332,25$ Nov. 1926. p. (16); no 348, 17 Mar. 1927. p. (13). - "A mascara dum poeta-filosofo", $A B C$, Ano 7, n 332, 30 Dez. 1926. p. (11).

MADUREIRA, M. Álvaro V. - "Antero", in A Dor. Porto, Editora Educação Nacional, 1943. p. 136-145.

MAGAlHÃES, Luís de - "Antero de Quental", A Província, Porto, 25 Set. 1891.

- Antero em Vila-do-Conde. Guimarães, Liceu de Guimarães, 1942. $18 \mathrm{p}$.

_-"Romagem a Santo Antero", Correiodos Açores, Ponta Delgada, 11 Set. 1923. p.1.

- "A sepultura de Antero", Correio dos Açores, Ponta Delgada, 19 Junho 1921. p. 1-2.

- "A vida de Anthero", in Anthero de Quental. In Memoriam. Porto, Mathieu Lugan, Ed., 1896. p. 115-137.

MAIA, Francisco Machado de Faria e - "Antero de quental (Esboço psychologico)", in Anthero de Quental. In Memoriam. Porto, Mathieu Lugan, Ed., 1896. p. 8-15.

- "Antero de Quental e o germanismo", Revista Portugueza, 1, Porto, 1895. p. 8-15.

MAIA, Jacinto Machado de Faria e - Em volta d'Anthero. Ponta Delgada, Oficina de Artes Gráficas, 1924. 
MAIA, João Machado de Faria e - "Antero de Quental", Diário de Anúncios, Ponta Delgada, 23 e 24 Set. 1891.

- "Anthero de Quental", Nova Alvorada, Anno 2, n 5 , Vila Nova de Famalicão, 1 Jul. 1892. p. 145-146.

- "Anthero de Quental - A Philosophia da natureza dos naturalistas...", Nova Alvorada, $4^{\circ}$ Anno, Vila Nova de Famalicão, ${ }^{\circ} 4$, 1 Jul. 1894. p. 136; n 7, 1 Out. 1894. p. 158-159; n $^{\circ} 9,1$ Out. 1894. p. 180.

- "Ciência e metafísica no pensamento anteriano", in Antero de Quental, Tendências gerais da filosofia na segunda metade do século XIX. Lisboa, Ed. Comunicação, 1989.

- "Memórias", in Anthero de Quental. In Memoriam. Porto, Mathieu Lugan, Ed., 1896. p. 145-200.

- "Teofilo Braga e Antero de Quental", Actualidade, Ponta Delgada, 1, 8, 22 e 29 Set. e 25 Out. 1891.

- "Teбfilo e Antero de Quental. Echos do Reporter X", Nova Alvorada, Anno 9, n 10, Vila Nova de Famalicão, Maio 1902. p. 73-74.

- "Uma ideia litteraria de Anthero de Quental", Nova Alvorada, $5^{\circ}$ anno, $n^{\circ} 4$, Vila Nova de Famalicão, Jul. 1895. p. 28-29.

MAIA, M. A. Machado de Faria e - "Recordações queridas", in Anthero de Quental. In Memoriam. Porto, Mathieu Lugan, Ed., 1896. p. 427-439.

MAIA, Visconde de Faria e - "Recordações de família e impressões pessoaes", in Anthero de Quental. In Memoriam. Porto, Mathieu Lugan, Ed., 1896. p. 349-365.

MALAPERT, Louis - "Cadencias vagas por Anthero de Quental", Nova Alvorada, Anno 2, n 4, Vila Nova de Famalicão, 1 Jul. 1892. p. 138-139.

MALPIQUE, Cruz - Antero, clássico de primeira água. Aveiro, Lusitânia, 1957. 15 p.

- "Física e metafísica do suicídio de Antero de Quental", Labor, Aveiro, 225, 1963. p. 145-171; 226, 1963. p. 249-279.

- "Umas quantas notas a esmo sobre Antero", Labor, Aveiro, 221, 1963. p. 519-529; 222, 1963. p. 577-587.

MANSO, Joaquim - "Antero de Quental", in $O$ pórtico e a nave. Lisboa, Ática, 1943. p. 107-125.

- "Opiniões sobre Antero de Quental. O lirismo de Antero", 
A Ilha, Ponta Delgada, 19 Abr. 1941. p. 6, 10.

- "Antero de Quental", in A consciência nua e abandonada.

Lisboa, Livraria Bertrand, 1938. p. 147-171.

MARINHO, José - "Antero, pensador do absoluto", in Antero de Quental, Tendências gerais da filosofia na segunda metade do século XIX. Lisboa, Ed. Comunicação, 1989.

- "Antero de Quental e os caminhos da união perdida", in

Verdade, condição e destinono pensamento contemporâneo. Porto,

Lello \& Irmão, 1976. p. 39-55.

- O pensamento filosófico de Leonardo Coimbra. Introdução ao

seu estudo. Porto, Livraria Figueirinhas, 1945. 202 p.

- "Perspectiva crítica do divino nos 'Sonetos' de Antero", Seara Nova, 406-408, Lisboa, 1934. p. 354-355.

MARINHO, Maria José - "Da vida sentimental de Antero", Diário de Lisboa, Lisboa, 26 Fev. 1981. p. 3.

- "A proposito de uma carta de Filomeno da Câmara para Jaime Batalha Reis sobre a doença de Antero", Revista da Biblioteca Nacional, 1(2), Lisboa, 1981. p. 295-300.

- "A propósito de uma carta de Oliveira Martins a Antero de

Quental sobre a estadia deste em Santa Eufémia", Revista da Biblioteca Nacional, 2(1), Lisboa, 1982. p. 129-132 il.

MARQUES, Henrique - "Casa de Anthero de Quental", Revista Illustrada, 2(37), Lisboa, Out. 1891. p. 228.

MARQUES, Ângelo Raposo - Antero e o Cristianismo. Ponta Delgada, Tip. do Diário dos Açores, 1955. 26 p.

- "Antero e Teofilo. (Entrevista com o Prof. Joaquim de Carvalho)", Correio dos Açores, Ponta Delgada, 23 Jan. 1949. p. 1 e 4. - O ideal revolucionário na concepção de arte de Antero. Coimbra, Casa Minerva, 1951. 14 p.

- Positivismo e anti-positivismo em Antero. Sep. de Biblos, Coimbra, 27, 1952. $26 \mathrm{p}$.

- O socialismo de Antero. Tentativa de interpretação. Coimbra, Ed. do Autor, 1949. 209+XVI p. Tese de licenciatura policopiada. - O socialismo de Antero. Tentativa de interpretação. Coimbra, Coimbra Editora, 1959. 228 p.

MÁRTENS, João Baptista da Silva Ferrão de Carvalho - Discurso sobre a suppressão das conferencias democraticas do Casino Lisbonense proferidona Câmara dos Senhores Deputados.... Lisboa, 
Imprensa Nacional, 1871.

MARTINEZ, Maria Teresa Leal de - "A filosofia idealista da morte em Antero de Quental", Ocidente, 400, Lisboa, 1971. p. 82-98.

MARTINS, Ana Maria Almeida - "Antero: As cartas de uma vida e uma carta (notável) a Oliveira Martins", "Ler Livros \& Leitores" Círculo de Leitores, 8, Lisboa, 1989. p. 48-50.

- "Antero: as datas de uma vida", JL-Jornal de Letras, Artes e Ideias, Ano XI, n 466, Lisboa, 11 Jun. 1991. p. 16-17.

- "Antero em Veneza", JL-Jornal de Letras, Artes e Ideias, Ano 7, n⿳2 253, Lisboa, 11 Maio 1987. p. 8-9.

- Antero de Quental. Fotobiografia. Lisboa, Imprensa Nacional-Casa da Moeda, 1985. 330 p.

- "Antero de Quental o professor de liceu que não chegou a ser",

Letras e Letras, Ano V, n 59, Porto, 20 Nov. 1991. p. 15.

- "Antero de Quental e Sousa Martins", Revista de Cultura Açoriana, Ano I, 1, Lisboa, 1989. p. 65-72.

- "Cartas inéditas de Antero a João de Deus", JL-Jornal de Letras, Artes e. Ideias, Lisboa, 19 Set. 1991. p. 8.

- "Centenários e centenaristas - No centenário de Antero de Quental", Adágio, Ano 1, série 1, 5-6, Évora, Jul.-Ago. 1991. p. 5$-7$.

- "Curros Enriques tradutor de Antero", Nosa Cultura, 9, Vigo, Dez. 1987. p. 72-73.

- "Dois testamentos contraditórios", Diário de Notícias, Caderno

2: "Antero de Quental, O príncipe da agonia", Lisboa, 12 Maio 1991. p. 9-10.

- "Eça de Queirós e o 'In Memoriam a Antero de Quental"', Revista de História das Ideias, 13, Coimbra, 1991. p. 379-386.

-Oessencial sobre Antero de Quental. Lisboa, Imprensa Nacional-Casa da Moeda, 1985. 47+8 p.

- "Manuel de Arriaga e Antero de Quental", Revista de Cultura Açoriana, 3, Lisboa, 1991. p. 5-16.

- "Raios de extinta luz: um título envenenado", Prelo, 3, Lisboa, 1984. p. 31-38.

- "Revelações de grande interesse: cartas inéditas de Antero de Quental", JL-Jornal de Letras, Artes e Ideias, Ano 5, n 180, Lisboa, 18 Maio 1985. p. 14-15. - "Um albúm perdido", Diário de Notícias, Supl. "Cultura", Lis- 
boa, 5 Jul. 1987. p. V.

- "Um retrato interrogativo", JL-Jornal de Letras, Artes e Ideias, Ano XI, n 466, Lisboa, 11 Jun. 1991. p. 20.

- e MARTINS, Guilherme d'Oliveira - "Cartas inéditas de

Antero para Oliveira Martins", Prelo, 7, Lisboa, 1985. p. 101-113 il.

MARTINS, Anabela Figueiredo - Como alguns escritores da "Geração de 70" viram a França. Lisboa, Faculdade de Letras, 1962. $210 \mathrm{p}$. Tese de licenciatura policopiada.

MARTINS, António Coimbra - "Um soneto anteriano", JL-Jornal de Letras, Artes e Ideias, Ano 1, $\mathrm{n}^{\circ}$ 19, Lisboa, 10 Nov. 1981. p. 9. MARTINS, F. A. Oliveira - "Antero de Quental e o 'Ultimatum"', Diário de Lisboa, Suplemento Literário, Lisboa, 21 Jun. 1935. p. 1. - "Antero e Oliveira Martins. Notas sobre o fim trágico do poeta", Ocidente, 18(53), Lisboa, 1942. p. 32-41.

- "Antero de Quental na mão de Deus", Ocidente, Lisboa, 1971, 80(393), p. 1-16; 80 (394), p. 17-31; (80) 395, p. 33-54.

- Uma página de duas literaturas. Antero de Quental na perspectiva de D. José Maria de Parede. Porto, Associação Portuguesa para o Progresso das Ciências, 1962. 14 p.

MARTINS, Guilherme d'Oliveira - "O início de uma amizade", $J L$ -Jornal de Letras, Artes e Ideias, Ano XI, n 466, Lisboa, 11 Jun. 1991.p. 16-17.

MARTINS, J. P. Oliveira - "Antero de Quental", in Perfis. Lisboa, Parceria António Maria Pereira, 1930. p. 43-67.

- "Uma carta inédita de Oliveira Martins a respeito do suicídio de Antero. Com anotações de Ruy Galvão de Carvalho", Ocidente, 21(65), Lisboa, 1943. p. 5-6.

- "Literatura e filosofia", in Obras completas. Lisboa, Guimarães e C $C^{a}, 1955$. p. 1-20.

- "O mal do século", in Anthero de Quental. In Memoriam. Porto, Mathieu Lugan, Ed., 1896. p. 59-67.

MARTINS, J.T. de Sousa - "Nosographia de Anthero", in Anthero de Quental. In Memoriam. Porto, Mathieu Lugan, Ed., 1896. p. 219$-314$.

MARTINS, J. V. de Pina - "Antero de Quental e Michelet", Arquivos do Centro Cultural Português, 8, Paris, 1974. p. 627-637. - A ideia de Deus e da morte na poesia de Antero. Monografia 
crítica. Coimbra, Ed. do Autor, 1948. XV+279 p. Tese de licenciatura dactilografada.

MARTINS, José Simões de Oliveira - "Anthero de Quental", Revista Illustrada, 1(1-2), Lisboa, Abr. 1890. p. 3 e 16-17.

MARTINS, Rocha - "Antero de Quental e o proletariado português", Diário da Tarde, Lisboa, 18 Dez. 1925. p. 4.

- Antero de Quental e o socialismo. Lisboa, Ed. Excelsior, s.d.. $32 \mathrm{p}$.

MARTOCQ, Bernard - "Molière, Castilho e a Geração de 70", Colóquio/Letras, 28, Lisboa, 1975. p. 39-46.

MATOS, Manuel Cadafaz de - "Antero e a história da imprensa oitocentista", Diário de Notícias, Caderno 2: "Antero de Quental, O príncipe da agonia", Lisboa, 12 Maio 1991. p.11.

MAURíCIO, Domingos - "A penitência dos 'Vencidos da Vida", Brotéria, 332, Lisboa, 1941. p. 288-294.

MEDEIROS, Fernando Saboia de - Anthero de Quental: Technica e inspiração dos seus sonetos. Rio de Janeiro, Ed. S.A. A Noite, s.d.. p. 395.

MEDINA, João - As Conferências do Casino e o Socialismo em Portugal. Lisboa, Publicações D. Quixote, 1984. 478 p.

- "A Geração de 70: uma síntese provisória", Colóquio/Letras, 28, Lisboa, 1975. p. 25-33.

- "Herculano visto por Antero, Eça, ...", in Herculano e a Geração de 70. Lisboa, Terra Livre, 1977. p. 13-21.

MEIRA, João - "Antero de Quental", Revista de Guimarães, 31, Guimarães, 1921. p. 190-201.

MELO, Alírio Gomes de - "A rima em Castro Alves e Antero", in A rima de alguns poetas. Coimbra, s.n., 1942. p. 11-13.

MELO, Lúcia Costa - Ensaio de uma perspectiva surrealista na vida e na obra de Antero de Quental. Ponta Delgada, Instituto Cultural, 1978. $261 \mathrm{p}$.

MENDES, Alexandre Teixeira - "Antero: a nobreza do fracasso", $O$ Primeiro de Janeiro, Suplemento "Domingo", 16 Jun. 1991. p. 14. MENDES, João - "Antero e o complexo de Caronte", Brotéria, 93(11), Lisboa, Nov. 1971. p. 479-491.

_ "Os dois Anteros", Brotéria, 76(1), Lisboa, 1963. p. 5-23.

- "Ética e estética de Antero", Brotéria, 76 (3), Lisboa, 1963. p. 257-281. 


\section{Elementos para uma bibliografia}

- "Os Sonetos de Antero", Brotéria, 55, Lisboa, 1963. p. 453-459 .

MENDES, José M. Amado - "Antero de Quental e Alberto Sampaio: observadores atentos da história imediata", Revista de História das Ideias, 13, Coimbra, 1991. p. 271-282.

MENDES, Macedo - "Antero e a revolução de 68 em Espanha", Pensamento, Porto, Ano 7, vol. 5, n. ${ }^{\circ} 78,1936$. p. 2-3.

MENDES, Manuel - Antero de Quental. Lisboa, Cosmos Editora, 1942. 133 p. il.

- A Geração de 1870. Lisboa, Jornal do Fôro, 1960. 344 p.

- "Sobre a personalidadee a obra de Antero", Seara Nova, Lisboa, 1925, 55. p. 128-130; 56. p. 155-157; 64. p. 65-76.

MENESES, Bourbon e - "Antero", in Páginas de combate. Crítica \& Doutrina. Lisboa, Livraria Central Editora de Gomes Carvalho, s.d. p. 233-239.

- "Uma carta sobre Antero", Diário de Notícias, 6 Jan. 1934. p. 1.

- O génio e o coração de Antero. Lisboa, Ed. Couto Martins, 1934. $79 \mathrm{p}$.

MENESES, José de Azevedo d' - Bibliographia antheriana. A propósito da "Resposta" do sr. Joaquim de Araújo aos srs. Delfim Gomes e José Pereira de Sampaio. Barcelos, Typ. do Aurora do Cávado, (1897). 15 p.

MIRANDA, José Carlos de - "O conflito existencial e a imaginação aérea. A dialéctica das imagens recorrentes nos Sonetos de Antero de Quental", Brotéria, 118(2), Lisboa, 1984. p. 174-181.

MODERNO, Alice - "Os ultimos dias de Anthero. Carta ao snr. Joaquim de Araújo", Nova Alvorada, Anno 1, nº 7, Vila Nova de Famalicão, 1 Nov. 1891. p. 64-65.

- "Tributo singelo", in Anthero de Quental. In Memoriam. Porto, Mathieu Lugan, Ed., 1896. p. 201-210.

MOISÉS, Carlos Filipe - "Antero de Quental. O poeta e o mito", Colóquio/Letras, 41, Lisboa, 1978. p. 36-44 il.

MOLARINHO, António - Lira romântica. Meridionais. Com uma carta de Anthero de Quental. Coimbra, Coimbra Editora, 1921. $159 \mathrm{p}$.

MONCADA, Luís de Cabral de - "Para a história da filosofia em Portugal no século XX", Boletim da Faculdade de Direito de 
Coimbra, 36, Coimbra, 1960. p. 1-15.

MONTALEGRE, Duarte - "Leopardi e Antero de Quental", Revista do Norte, 1(4), Porto, 1955. p. 93-96.

MONTEIRO, Adolfo Casais - "Anthero de Quental", Seara Nova, 38(767), Lisboa, 1942. p. 166-167.

- "Os objectivos morais na obra de Antero", in Confronto Antologia de escritores modernos, vol. 2, Coimbra, 1946. p. 82-98. MONTEIRO, Gomes - "Antero e Teofilo", in Vencidos da Vida: relance literário e político da segunda metade do séc. XIX. Lisboa, Romano Torres, 1944. p. 81-96.

- "Santo Antero!... Santo Antero!...", in Vencidos da vida: relance literário e político da segunda metade do séc. XIX. Lisboa, Romano Torres, 1944. p. 97-116.

MONTENEGRO, Aura - "Antero de Quental. Subsídios para uma revisão das suas fontes", Biblos, 52, Coimbra, 1976. p. 153-162.

"Monumento a Antero de Quental", Arquivo Coimbrão, 17, Coimbra, 1959. p. 1-19.

"Monumento a Antero de Quental", $A B C$, Ano 6, n 301, Lisboa, 22 Abr. 1926. p. (8).

MOOG, Ana Maria - "Convergência e divergências no pensamento de Antero de Quental e Tobias Barreto: o tema moral", in $O$ pensamento de Tobias Barreto, Lisboa, Universidade Nova de Lisboa, 1991. p. 107-117.

MOOG, Viana - Eça de Queirós e o século XIX. Porto Alegre, Livraria Globo, 1939. p. 23-74.

MORAIS, Carlos Dante de - A inquietação e o fim trágico de Antero de Quental. Porto-Alegre, Livraria do Globo, 1939. 151 p.

MORAIS, Casimiro Augusto - Antero de Quental tipógrafo-amador ou um profissional assalariado? Lisboa, Império, 1943. 14 p.

MOTA, Aristides - "Alguns apontamentos acerca de Antero", Correio dos Açores, Ponta Delgada, 17 Abr. 1921.p. 1-2.

- "Antero de Quental", Alma Académica, 5, Ponta Delgada, 1922.

- "O mar e o vento na obra de Anthero", Correio dos Açores,

Ponta Delgada, 17 Abr. 1921. p. 2.

- "A propósito de Antero", Diário dos Açores, Ponta Delgada, 20 Nov. 1930. p. 1.

MOTA, Fernando - "Pensamento jurídico de Antero", Pensamento, Porto, Ano 7,vol.5, n. ${ }^{\circ} 78,1936$. p. 11. 
MOTA, Jorge César - "A religião na obra e na personalidade de Antero de Quental", Revista de Letras, 13, Assis, 1970-71.p. 67-99. MOURA, João Lobo de - "O fim do poeta", in Anthero de Quental. In Memoriam. Porto, Mathieu Lugan, Ed., 1896. p. 139-143.

NABAIS, Nuno - "O filósofo quase possível", $O$ Público, Lisboa, 7 Jun. 1991. p. 10-11.

NASCIMENTO, Luzia Garcia do-Confluência de ideias filosóficas em 'Odes Modernas' de Antero de Quental. São Luís, Universidade Federal do Maranhão, 1979. 3+34 p.

NAZARÉ, Cândido - "Antero de Quental em Coimbra", Correio dos Açores, Ponta Delgada, 11 Set. 1929. p. 1.

NEMÉSIO, Vitorino - "Antero de Quental et la grande génération", in Études portugaises: Gil Vicente, Herculano, Antero de Quental, le symbolisme. Lisboa, Instituto para a Alta Cultura, 1938. p. 97$-130$.

- "Antero e Herculano", Seara Nova, 406-408, Lisboa, 1934. p. 349-353.

- "O monge", in Sob os signos de agora. Coimbra, Imprensa da Universidade, 1932. p. 156-140.

- "Nota sobre Antero", Aventura, 2, Lisboa, 1942. p. 51-52.

NEVES, Ester - Antero de Quental, Hegel e Eduard Hartmann. Coimbra, Ed. do Autor, 1935. 58 p. Tese de licenciatura policopiada.

NEVES, Henrique - "Antero de Quental", in Esbocetos individuais. Traços característicos, episódios e anedotas autênticas de indivíduos que se evidenciaram. Lisboa, Livraria Editora, 1911. p. 105-120.

NEVES, Maria do Céu Patrão - "Influência da filosofia francesa nos escritos filosóficos de Antero", Revista Portuguesa de Filosofia, 47(2), Braga, 1991. p. 375-386.

NEVES, P.e. Moreira das - "Antero e o suicídio sob a âncora", in $O$ grupo dos cinco. Lisboa, Livraria Bertrand, 1945. p. 29-80.

No centenário de Antero. Vila do Conde, Câmara Municipal de Vila do Conde, $1942.66+5$ p. il.

NOBRE, Carminé - "Festejando uma data", Diário de Coimbra, Coimbra, 18 Abr. 1942. p. 1.

NOGUEIRA, César - Antero de Quental. Esboço da sua biografia político-social. Lisboa, Ed. do Autor, 1950. 73 p. 
-"Antero de Quental. Jornalista", Gazeta Literária, 3(36-37), 1955. p. 56-57.

- "Apontamentos para a biografia política de Antero de Quental", Pensamento, 116, Porto, 1939. p. 2-226; 5-229 il.

- "A biografia de Antero de Quental", Seara Nova, 1246-47, Lisboa, 1952. p. 29-31.

- "O nosso Antero", Pensamlento, Porto, Ano 7, vol. 5, n. ${ }^{\circ} 78$, 1936. p. 8.

NORONHA, F. - "Antero de Quental", A Publicidade, Lisboa, n. ${ }^{\circ}$ 95, 1944. p. 1-2.

NÓVOA, António - "Antero e a Sociedade do Raio", Revista de História das Ideias, 13, Coimbra, 1991. p. 231-269+ in.

- "A Sociedade do Raio na Coimbra académica de 1861-1863", in Universidade(s). História. Memória. Perspectivas. Actas do Congresso "História da Universidade". Coimbra, Comissão Organizadora do Congresso, 1991, vol. 3. p. 277-320.

"As obras completas de Antero de Quental", JL-Jornal de Letras, Artes e. Ideias, Ano IX, $\mathrm{n}^{\circ} 365$, Lisboa, 4 Jul. 1989. p. 15.

OLIVEIRA, Alberto de - "Antero de Quental em versos francezes", in Pombos correios, Coimbra, França Amado Editor, 1913. p.135$-141$.

OlIVEIRA, César de - O Socialismo em Portugal. Porto, Ed. do Autor, 1973. $404 \mathrm{p}$.

OLIVEIRA, Emídio de - "Antero de Quental", in A carteira de um latino. Porto, Centro Internacional Publicações-Editor. 1893. p. 285-289.

OLIVEIRA, Lopes de - "Evocação de Antero e a sua geração", in Eça de Queirós. Lisboa, Vida Mundial Editora, 1944. p. 17-35.

OLIVEIRA, Manuel Moura - Antero de Quental. Ideias filosóficas e concepçóes religiosas. Coimbra, Ed. do Autor, 1942. Tese de licenciatura policopiada.

ORTIGÃO, Ramalho - "Litteratura de hoje. Manuel PinheiroChagas, António Feliciano de Castilho, Vieira de Castro, Antero de Quental, Téffilo Braga", in Figuras e questões literárias. vol. 1. Lisboa, Livraria Clássica Editora, 1943. p. 5-97.

OSÓRIO, Pinto (sob o pseud. de Pedro Eurico) - "Antero de Quental", in Figuras do passado. Lisboa, Typ. Ed. José Bastos, 1915. p. 77-120 il. 


\section{Elementos para uma bibliografia}

OSÓRIO, Pinto - "Nomes de muitos estudantes. Téffilo Braga. Antero de Quental", in Lembranças da mocidade. Porto, Empreza Litteraria e Typographica, 1907. p. 155-167. - "A rolinada. Sua origem e sequência. A nobre figura do estudante Antero de Quental", in Lembranças da mocidade. Porto, Empreza Litteraria e Typographica, 1907. p. 63-79.

PACHECO, Eugénio-A propósito do catálogo da Antheriana, Ponta Delgada, Typo-Lytographia Ferreira, 1890. 28 p.

_- "Bibliographia antheriana", Nova Alvorada, Anno 8, n² 2, Vila Nova de Famalicão. p. 113-114.

O palácio da ventura. Introd. de Julião Quintinha. Lisboa, A Voz do Operário, 1942(?).

PATO, Bulhão - "Antero de Quental", in Memórias. Scenas e homens de lettras. vol. 1. Lisboa, Academia Real das Sciencias, 1894. p. 293-336.

PATRÍCIO, Manuel Ferreira - "Antero, o analfabetismo e a demopedia", Diário Popular, 12 Set. 1991. p. 6.

PAVÃO, José de Almeida - "Antero e a morte", Contravento: Letras e. Artes, 4, Lisboa, 1971. p. 5-8.

- Antero e a morte. Ponta Delgada, Oficinas Tipográficas do Diário dos Açores, 1972. $17 \mathrm{p}$.

PAXECO, Fran - A escola coimbrã e a dissolução do Romantismo. Lisboa, Casa Ventura Abrantes, 1917. 362 p.

PAXECO, Óscar - " Antero de Quental", Diário de Notícias, Lisboa, 27 Jun. 1933.

PENHA, João - "Antero de Quental", A Águia, 14, 1918. p. 135. - "Anthero", Nova Alvorada, Anno 1, nº 7, Vila Nova de Famalicão, 1 Nov. 1891. p. 66.

PEREIRA, José Carlos Seabra - "Antero-Poesia, alta voz dramática". Revista de História das Ideias, 13, Coimbra, 1991. p. 193-220.

PEREIRA, José Maria dos Reis (José Régio) - "Antero de Quental. A sua obra e a sua época", in As correntes e as individualidades na moderna poesia portuguesa. Vila do Conde, s.n., 1925. p. 15-21.

PICOITO, Carlos da Costa - Quatro estudos em jeito de conferências. Faro, Tipografia União, 1966. 80 p.

PIMENTA, Alfredo - "Antero de Quental", in O livro das muitas e variadas coisas. Lisboa, Parc. António Maria Pereira, 1920. p. 163-171 . 
- "Anthero de Quental", in Sombras de Principes: Garrett, Herculano, Camilo, Anthero de Quental... Lisboa, Portugália Editora, 1920. p. 33-41.

- Mestres do pensamento. Braga, Ateneu Comercial de Braga, $1941.44 \mathrm{p}$.

PIMENTEL, Alberto - "Anthero de Quental", Nova Alvorada, Anno 1, nº 7, Vila Nova de Famalicão, 1 Nov. 1891. p. 70.

PIMPÃO, Álvaro Júlio da Costa - Antero de Quental e Baudelaire. Coimbra, Coimbra Editora, 1941. 14 p.

- Antero: o livro dos sonetos. Coimbra, Faculdade de Letras, 1942. $16 \mathrm{p}$.

- "Antero filosofo da santidade", in Gente grada. Coimbra, Atlântida, 1952. p. 63-70.

- O monumento de Antero. Conferência. s.l., s.n., 1951. 6p.

PINTO, Ilídio - "Antero educador da infância", Pensamento, Porto, Ano 7, vol. 5, n. ${ }^{\circ}$ 78, 1936. p. 19.

PIRES, António M. Machado - "Antero, apóstolo do socialismo proudhoniano", JL-Jornal de Letras, Artes e Ideias, Ano IX, $\mathrm{n}^{\circ} 363$, Lisboa, 20 Jun. 1989. p. 26.

- "Antero romântico", Revista de História das Ideias, 13, Coimbra, 1991. p. 165-177.

- "Antero de Quental. Apontamento biográfico", in Linguagem: linguagens e ensino. Ponta Delgada, Universidade dos Açores, 1981. p. 107-112.

- "Antero - a olímpica exemplaridade de uma Geração", Letras e Letras, Ano V, n 59, Porto, 20 Nov. 199. p. 11-12.

- "Antero peregrino", JL- Jornal de Letras, Artes e Ideias, Ano XI, no 466, Lisboa, 11 Jun. 1991. p. 20-21.

- "A crítica histórica de Antero nas Conferências do Casino e a sua projecção", in A ideia de decadência na Geração de 70. Ponta Delgada, Instituto Universitário dos Açores, 1980. p. 55-89.

- O século XIX em Portugal. Cronologia e quadros de gerações. Lisboa, Bertrand, 1975. 225 p.

- "Universalismo e identidade Nacional", in Almeida, Onésimo Teotónio (Dir.), Da literatura açoriana - subsídios para um balanço. Angra do Heroísmo, SREC, 1986. p. 285-301.

PIRES, Veiga - "Antero", Portucale, Porto, 3. a série, 1(1-2), 1951-52. p. 85-87. 


\section{Elementos para uma bibliografia}

PIRES, Videira - "O sentido estético da obra de Antero", Via Latina, 11, Coimbra, 15 Maio 1942. p. 3.

PITA, António Pedro - "O pensamento estético de Antero", Revista de História das Ideias, 13, Coimbra, 1991. p. 111-133.

Poetas do século XIX: Almeida Garrett, Antero de Quental, Cesário Verde. Porto, Porto Editora, 1978. 111 p.

PORTELA, Severo - A crença de Anthero. Coimbra, Imprensa da Universidade, $1899.43 \mathrm{p}$.

- A mãe de Anthero. Lisboa, Edições Lusitânia, 1923. 23 p. il.

PORTOCARRERO, Rui - Lisboa, Coimbra e Porto e a questão litteraria. A carta do Snr. Anthero de Quental ante os Snrs. Pinheiro Chagas, M. Roussado e J. de Castilho. Lisboa, Typographia Universal, 1866. $39 \mathrm{p}$.

PORTUGAL, Miguel - "Um novo estudo sobre a personalidade de Antero de Quental", Vértice, 10, Coimbra, 1950. p. 443-444.

PRAÇA, Afonso - "Congresso Internacional. Um olhar plural e diverso sobre Antero", JL-Jornal de Letras, Artes e Ideias, $\mathrm{n}^{\circ} 485$, Lisboa, 22 Out. 1991.p. 14-15.

PRETO, Rolão - "O eixo Antero-António Sardinha", in Para além da guerra. Lisboa, Ed. Gama, 1942. p. 19-36.

PROENÇA, Adriano - "Antero 'o santo'", Diário de Coimbra, Coimbra, 19 Abr. 1942. p. 1.

QUADROS, António - "Antero: a questa, a odisseia, a peregrinação do poeta-filósofo e do poeta religioso", Revista Portuguesa de Filosofia, 47(2), Braga, 1991. p. 265-279.

QUEIRÓS, Eça de - "Antero de Quental", in Homens e idéias do século XIX (Antologia). Rio de Janeiro. p. 242-285.

- "Antero de Quental", in Notas contemporâneas. Porto, Lelo e Irmão, 1909. p. 349-404.

- "Um génio que era um santo", in Anthero de Quental. In Memoriam. Porto, Mathieu Lugan, Ed., 1896. p. 481-522.

QUINTINHA, Julião - "A propósito do monumento a Antero de Quental", in Imagens da actualidade. Lisboa, Editor Nunes de Carvalho, 1933. p. 111-208.

R., P. - "Antero coimbrão e a sua obra admirável", Diário de Coimbra, Coimbra, 14 Abr. 1942. p. 1.

RAMOS, Aníbal - Dois grandes amigos Antero de Quental e Jaime Batalha Reis. Ponta Delgada, Instituto Cultural,1985. 20 p. 
- Antero de Quental, Leão Tolstoi e Jaime de Magalhães Lima. Ponta Delgada, Instituto Cultural, 1988. 15 p.

RAMOS, Feliciano - "Antero nas Primaveras românticas", in Ensaios de crítica literária. Coimbra, Imprensa da Universidade, 1933. p. 115-135.

- Antero de Quental na poesia filosófica. Vila do Conde, Tip. do Reformatório, 1936. XI+130 p. il.

- "Antero no 'Tesouro poético da infância'", Gil Vicente, 18(5-6), Guimarães, 1942. p. 69-78.

- "A estética poética de Antero de Quental", Nação Portuguesa, 1(3), Lisboa, 1929. p. 149-160.

- A expressão da liberdade em Antero e os "Vencidos da Vida". Lisboa, Editorial Império, 1942. $110 \mathrm{p}$.

RAMOS, Rui Monteiro - "Contra a Geração de 70", Expresso, Revista, 7 Set. 1991. p. 36R-38R.

RECH, Bruno - "Krisis und Erneuerung des portugiesischen Denkens: Antero de Quental und Eça de Queirós", Geistige Arbeit, 4(1-3), Berlin, 1937.

"Reflexões sobre Antero", Açoriano Oriental, Ponta Delgada, 17 Out. 1991. p. I e IV.

RÉGIO, José - "Em louvor dos Sonetos", Diário de Notícias, Caderno 2, Lisboa, 12 Maio 1991. p. 5.

- "Introdução a um estudo sobre a arte de Antero", Seara Nova, 406-408, Lisboa, 1934. p. 358-361.

REGO, Alberto - "Antero e Beethoven", Estudos, 206, Coimbra, 1942. p. 159-169.

REGO, José Lins do - "Antero de Quental", in Gordos e magros. Rio de Janeiro, Edição da Casa do Estudante do Brasil, 1942. p. 151-155 .

REGUEIRO, Xesús Torres - "Antero, Curros e Vesteiro. A propósito do centenário dun suicídio", A Nosa Terra. Supl. Guieiro Cultural, 502, Vigo, 19 Dez. 1991. p. 20.

REIS, Câmara - "Grandeza moral de Antero", Pensamento, Porto, Ano 7, vol. 5, n. ${ }^{\circ} 78,1936$. p. 18.

- "Sobre Antero e a música", Seara Nova, 406-408, Lisboa, 1934. p. 363-365.

REIS, Carlos - As Conferências do Casino. Lisboa, Publicações Alfa, 1991. 


\section{Elementos para uma bibliografia}

- "Um bardo dos tempos novos: a imagem queirosiana de Antero", Revista de História das Ideias, 13, Coimbra, 1991. p. 179-191. REIS, Jaime Batalha - "Annos de Lisboa. (Algumas recordações)", in Anthero de Quental. In Memoriam. Porto, Mathieu Lugan, Ed., 1896. p. 441-472.

- "Antero, Fontana e as Conferências do Casino", in João Medina, As Conferências do Casino e o Socialismo em Portugal, Lisboa, Dom Quixote, 1984. p. 160-177.

"Resumo das disposições de Anthero de Quental segundo a cópia enviada pelo Sr. Arruda Quental à Exmª $\mathrm{Sr}^{2} \mathrm{D}$. Alice Moderno", Nova Alvorada, Anno 1, nº 7, Vila Nova de Famalicão, 1 Nov. 1891. p. 65.

RIBEIRO, António Camilo - "Considerações sobre a estética de um poeta pessimista", Revista de História das Ideias, 13, Coimbra, 1991. p. 161-164.

RIBEIRO, Luís - "O regionalismo açoreano na obra de Antero de Quental", Correio dos Açores, 10 Set. 1922. p. 3.

ROCHA, Acílio da Silva Estanqueiro - "Proudhon e o socialismo anteriano", Revista Portuguesa de Filosofia, 47(2), Braga, 1991. p. 349-374.

ROCHA, Augusto - Anthero de Quental. Perfil Psíquico. Coimbra, Imprensa Académica, $1900.34 \mathrm{p}$.

ROCHA, Júlio d'Oliveira - "Anthero de Quental. Documentos ineditos para a sua biographia", Nova Alvorada, $6^{\circ}$ Anno, $\mathrm{n}^{\circ} 2$, V ila Nova de Famalicão, Maio 1896. p. 105.

ROCHA, Rui - "O homem que queria ser um", Expresso, Revista, 7 Set. 1991.p. 34 R.

RODRIGUES, Anna Maria Moog - "O Absoluto no pensamento de Antero e em posteriores filósofos portugueses", Revista Portuguesa de Filosofia, 47(2), Braga, 1991. p. 247-253.

- "A filosofia de Antero de Quental", Revista Portuguesa de Filosofia. Actas do Congresso Luso-Brasileiro de Filosofia, 3 (4), Braga, 1982. p. 842-863.

RODRIGUES, António Basílio - "Herculano e Antero", Convergência, 2(3), Rio de Janeiro, 1977. p. 193-196 il.

ROMARÍS PAIS, Andrés - "Los sonetos del 'Elogio da Morte' de Antero de Quental", Colóquio/Letras, 69, Lisboa, Set. 1982.p. 11$-19$. 
ROMEO JUNIOR, S. - As letras no Brazil. Duas palavras acerca de umfolheto do Snr. Antero de Quental. Braga, Typ. de Domingos G. Gouveia, 1866. $10 \mathrm{p}$.

ROSA, Alberto Machado - "'Boémia espirituosa' em Coimbra", Revista da Faculdade de Letras, $3^{\mathrm{a}}$ série, 13, Lisboa, 1971. p. 361-376.

ROSA, Eduardo Ferraz da - "Uma hermenêutica trágica da experiência do mistério: finitude e esperança em Antero", Revista Portuguesa de Filosofia, 47(2), Braga, 1991. p. 311-323.

ROSSEL, Virgile - Un grand poète portugais du XIXe siècle. Poèmes et sonnets par Anthero de Quental. Traduits en français et précédés d'une notice biographique et littéraire. Lausanne, Payot et Cie., (1911). $138 \mathrm{p}$.

RUAS, Henrique Barrilaro - "Sob o signo de Antero", Diário de Notícias, Lisboa, 29 Abr. 1991. p. 10.

RUMBUCHER, Klara - Antero de Quental. Munchen, Max Hueber Verlag, 1968. $110 \mathrm{p}$.

SÁ, Víctor - "Antero e Alberto Sampaio no Norte", Jornal de Notícias, Porto, 3 Jul. 1979. p. 13.

- "Antero: cem anos depois", O Comércio do Porto, Porto, 10 Maio 1966. p. 14.

- "Antero, intelectual intervencionista", O Comércio do Porto, Porto, 24 Abr. 1962. p. 5 il.

- "Antero e a $1^{\text {a }}$ Internacional", República, Lisboa, 28 Fev. 1963.

p. 1 e 11.

- Antero de Quental. Braga, Ed. do Autor, 1963. 339 p.

- Antero de Quental. $2^{\mathrm{a}}$ ed.. Porto, Ed. Limiar, 1977. 286+ 6 p.

- "Antero e Teófilo na diferenciação das correntes socialista e republicana", Diário de Lisboa, Lisboa, 21 Mar. 1963. p. 19 e 22.

- "Identidade de Antero com Proudhon", O Comércio do Porto, Porto, 12 Mar. 1963. p. 5.

- "A mocidade de Antero: apontamentos coligidos para um ensaio biográfico", Jornal de Ílhavo, Ílhavo, 20 Abr. 1941. p. 3 e 4; 27 Abr. 1941. p. 2.

- A mocidade de Antero. Braga, Ed. Futuro, 1942. 90 p.

- "Perfis que são história. Alberto Sampaio e Antero de Quental", in No mar do futuro. s.l., Livros Horizonte, 1980. p. 89-101.

- "Proudhon e Antero de Quental", O Comércio do Porto, Porto, 22 Jan. 1963. p. 5 il. 
- " (Re) lendo Antero", Norte Popular, Porto, 7 Out. 1983. p. 18. -"OSocialismoproudhoniano de Anterode Quental", OComércio do Porto, Porto, 9 Abr. 1963. p. 5 e 6.

- "Sobre o carácter do socialismo de Antero de Quental", A República, Lisboa, 14 Fev. 1959. p. 1 e 2.

SALAZAR, Abel - "Antero de Quental sob o ponto de vista caracteriológico", O Pensamento, Ano VII, 5 (78), Porto, Set. 1936. p. 14$-16$.

SALEMA, Álvaro - "Antero e o heroísmo de pensar", Seara Nova, 406-408, Lisboa, 1934. p. 377-378.

SALGADO, Eduardo Augusto - "Duas palavras acerca de um livro do Sr. Antero de Quental", in Literatura de Amanhan. Porto, Typ. do Commercio do Porto, 1866. 14 p.

SALGADO, Heliodoro - "Antero de Quental", O Século, Lisboa, 27 Set. 1891.

SALGADO JÚNIOR, António - "Antero e a Literatura infantil", Seara Nova, 406-408, Lisboa, 1934. p. 344-347.

- "Antero e os treze sonetos de Vila do Conde", in No Centenário de Antero, Vila do Conde, Câmara Municipal, 1942. p. 19-66.

- "Antero de Quental examinador no Liceu Nacional do Porto", O Tipeiro, Ano 3, 5, Porto, Set. 1947. p. 97-102.

- História das Conferências do Casino: 1871. Lisboa, s.n., 1930. $167 \mathrm{p}$.

- "Sobre uma 'História das Conferências do Casino': Carta a um crítico do 'Diário de Notícias'", Seara Nova, 12, Lisboa, 1929-1930. p. 331-341.

SAMPAIO, Alberto - "Anthero de Quental. (Recordações)", in Anthero de Quental. In Menoriam. Porto, Mathieu Lugan, Ed., 1896. p. 9-29.

- "Anthero de Quental. (Recordações)", in Estudos históricos e económicos. Porto, Livraria Chardron, 1923. p. 79-97

SANTOS, F. Reis - "O movimento republicano e a consciência nacional", in Montalvor, Luís de, História do regímen republicano em Portugal. Vol. I. Lisboa, Ed. Ática, 1930-32. p. 261-336.

SANTOS, Fernando Piteira - "Antero de Quental e o socialismo. Carta a Rocha Martins", Seara Nova, 978, Lisboa, 1946. p. 27-28. - "As 'Cartas' de Antero de Quental na edição das Obras Completas", JL-Jornal de Letras, Artes e Ideias, Ano X, nº 401, Lisboa, 13 
Mar. 1990. p. 13.

- "A lição de Raul Proença e uma atitude de Antero de Quental", Seara Nova, 1108, Lisboa, 1949. p. 127-128.

SANTOS, Leonel Ribeiro dos - "Antero e a arte", Revista de História das Ideias, 13, Coimbra, 1991. p. 135-160.

SARAGGA, Salomão - "A prosa de Anthero", in Anthero de Quental. In Memoriam. Porto, Mathieu Lugan, Ed., 1896. p. 69-71.

SARAIVA, António José - "Antero e as Campanhas de Itália", $J L$ -Jornal de Letras, Artes e. Ideias, Ano 7, n 244, Lisboa, 9 Mar. 1987. p. 9.

- "Antero e a Internacional", JL-Jornal de Letras, Artes e Ideias, Ano VI, n 199, Lisboa, 28 Abr. 1986. p. 4.

- "A duplicidade de Antero", Colóquio/Letras, 103, Lisboa, Maio-Junho 1988. p. 56-60.

- História da literatura portuguesa. Lisboa, Estúdios Cor, 1976. p. 217-234.

- "Oliveira Martins versus Antero de Quental", Colóquio/Letras, 106, Nov.-Dez., Lisboa, 1988. p. 26-28.

- A Tertúlia Ocidental. Estudos sobre Antero de Quental, Oliveira Martins, Eça de Queiroz e outros. Lisboa, Gradiva, 1990. $233 \mathrm{p}$.

e LOPES, Óscar-História da Literatura portuguesa. $6^{\mathrm{a}}$ ed.. Porto, Porto Editora, s.d. p. 875-881.

SARAIVA, Carlös - "Antero de Quental: a propósito do centenário do suicłdio do poeta açoreano", Psiquiatria Clínica, 12(1), Coimbra, 1991. p. 55-64.

SARDINHA, António - "A dor de Antero", in Ao ritmo da ampulheta. Lisboa, "Lumen" Empresa Internacional Editora, 1925. p.187-205.

- "O verdadeiro Antero", in Ao princípio era o verbo. Lisboa, Livraria Portugália Editora, 1924. p. 91-121.

SAVIOTTI, Gino - La poética di Antero. Lisboa, Editorial Império, 1943. 13 p.

SEABRA, José Augusto - "João de Deus e Antero de Quental. Uma afinidade poética electiva", JL-Jornal de Letras, Artes e Ideias, 483, Lisboa, 8 Out. 1991. p. 5.

- "Revolução e liberdade em Antero de Quental", JL-Jornal de Letras, Artes e Ideias, n 472, Lisboa, 23 Jul. 1991. p. 15. 


\section{Elementos para uma bibliografia}

SENA, Jorge de - "Antero revisitado", in Estudos de Literatura Portuguesa, Lisboa, Edições 70, 1982. p. 123-132.

SEQUEIRA, Gustavo de Matos - Fradique Mendes, símbolo dos Vencidos da Vida. Lisboa, s.n., 1942. 22 p.

SEQUEIRA, Montalverne de - "Ultimos momentos de Anthero", Correio dos Açores, Ponta Delgada, 10 Set. 1922. p. 1 e 4.

SÉRGIO, António - Antero de Quental e António Vieira perante a civilização cristã dos seus tempos. Porto, Biblioteca Fenianos, 1948. $32 \mathrm{p}$.

- "Antero de Quental contra Oliveira Martins no respeitante às fases da filosofia europeia e à evolução intelectual na Grécia antiga", in Ensaios, vol. VI. Lisboa, Ed. Inquérito, 1946. p. 19-66. - "Os dois Anteros", in Ensaios, vol. IV. Lisboa, Ed. Inquérito, 1934. p. 151-189.

- "Em torno da ilusão revolucionária de Antero", in Ensaios, vol.

V. Lisboa, Ed. Inquérito, 1936. p. 157-234.

- "Explicações sobre 'Os dois Antero'". Seara Nova, 488, Lisboa, 1936. p. 115-118.

- "Os estudantes promotores da trasladação dos restos mortais de Antero de Quental", A Águia, 109-111, Porto, 1921. p. 25-55. - Notas sobre os Sonetos e as Tendencias geraes da Philosophia de. Anthero de Quental. Lisboa, Livraria Ferreira Editora, 1909. $189 \mathrm{p}$.

- Perante a inexistência de uma civilização cristã. Depoimentos de Antero de Quental e António Vieira. $2^{\mathrm{a}}$ ed.. Lisboa, Inquérito, s.d.. 39 p.

- "A propósito de uma discussão entre Antero e Oliveira Martins", Mundo Literário, II ano, $\mathrm{n}^{\circ} 37,18$ Jan. 1947. p. 1-2.

- "Sobre o carácter do socialismo de Antero", in Ensaios, vol. VII.

Lisboa, Europa-América, 1954.

- "Sobre o socialismo de Antero", in Ensaios, vol. IV. Lisboa, Ed.

Inquérito, 1934. p.191-207.

- "As Tendências como poema metafísico e místico", in Antero de Quental, Tendências gerais da filosofia na segunda metade do século XIX. Lisboa, Ed. Comunicação, 1989.

- "Tese e antítese nos sonetos de Antero", Revista de Portugal, 1,

Coimbra, 1937. p. 16-32.

- Um problema anteriano (Sôbre a ideia e a realidade do des- 
prendimento activo na peregrinação moral do autor dos Sonetos). Lisboa, Ed. do Autor, s.d. 54 p.

SERRÃO, Joel - "Acerca da tendência heteronímica de Antero", in Afecto às Letras. Homenagem da literatura portuguesa contemporânea a Jacinto do Prado Coelho. Lisboa, Imprensa Nacional-Casa da Moeda, 1984. p. 311-319.

- "Acerca da tendência heteronímica de Anteroe Eça de Queiroz", in O primeiro Fradique Mendes. Lisboa, Livros Horizonte, 1985. p. $177-191$.

- "Antero e Castilho", JL-Jornal de Letras, Artes e Ideias, Ano 1, $\mathrm{n}^{\circ}$ 17, Lisboa, 13 Out. 1981. p. 6-7.

- "Antero e a destruição do Programa", in Portugueses somos. Lisboa, Livros Horizonte, 1975. p. 23-36.

- "Antero e Herculano", JL-Jornal de Letras, Artes e Ideias, Ano 1, no 10, Lisboa,7 Jul. 1981. p. 6-7.

- "Antero de Quental. Agosto de 1867 a Outubro 1868", Memórias da Academia de Ciências - Classe de Letras, 23, Lisboa, 1983. p. 231-250.

- "Antero de Quental nas origens da sua maneira de ser e de estar", in Estudos de História de Portugal. Homenagem a A.H. de Oliveira Marques. vol. 2. Lisboa, Ed. Estampa, 1983. p. 357-370.

- "Antero entre o ser e nada (1862-65)", Colóquio/Letras, nº 76, Lisboa, Nov. 1983. p. 28-34.

- "Antero em Paris (1866-1867)", Ler História, 3, Lisboa, 1984. p. 33-42.

- "Antero à procura de ocupação para a sua alma", in $O$ primeiro Fradique Mendes. Lisboa, Livros Horizonte, 1985. p. 13-95.

- "Antero: A ruptura com o passado e a inquietação metafísica. Nos primórdios da filosofia anteriana", Diário de Notícias. Supl. "Cultura", Lisboa, 5 Jul. 1987. p. IV-V.

- Antero e a ruína do seu programa. Lisboa, Livros Horizonte, 1988. $111 \mathrm{p}$.

- Antologia do pensamento político português. Vol. 1. Porto, Editorial Inova, 1970. $475 \mathrm{p}$.

- "Carta a Antero de Quental", Horizonte. Quinzenário Cultural, Lisboa, 12 Abr. 1942. p. 1 e 4.

- "Da poesia a filosofia", in Antero de Quental, 'Hino da manhã' e outras poesias do mesmo ciclo. Lisboa, Livros Horizonte, 


\section{Elementos para uma bibliografia}

$1989.83 \mathrm{p}$.

- "De Antero a Pessoa. Alguns rumos de investigação", Colóquio/ /Letras, 88, Lisboa, Nov. 1985. p. 9-16.

- "De Pessoa a Antero", in Actas do II Congresso Internacional de Estudos Pessoanos. Porto, Centro de Estudos Pessoanos, 1985.

p. 531-546.

- "Devir e Ser na filosofia anteriana", Arquivos do Centro Cultural Português, XXVII, Paris, 1990. p. 159-206.

- "Do pensamento político-social de Antero de Quental - 1868-1873", Análise Social, 16(61-62), Lisboa, 1980. p. 373-391.

- Do pensamento sócio-político de Antero de Quental: 1873-1889. Lisboa, Centro de História da Cultura da Universidade Nova de Lisboa, 1982. 18 p.

- "Duas cartas de Antero", JL- Jornal de Letras, Artes e Ideias, Ano XI, n 466, Lisboa, 11 Jun. 1991. p. 14-15.

- "Em busca do contexto do último escrito filosófico de Antero de Quental", Revista de História das Ideias, 13, Coimbra, 1991. p. 73-109.

- "Génese e estrutura do pensamento sócio-político de Antero de Quental", in Antero de Quental, Prosas sócio-políticas. Lisboa, Imprensa Nacional - Casa da Moeda, 1982. p. 9-95.

- Içar as velas e soltar os ventos. Lisboa, Livros Horizonte, 1989. $220 \mathrm{p}$.

- "Na pista dos motivos da destruição das 'Poesias Lúgubres", in Antero de Quental, 'Hino da manhã' e outras poesias do mesmo ciclo. Lisboa, Livros Horizonte, 1989. p. 7-38.

- "Nas origens da filosofia de Antero", Revista de Filosofia e. Epistemologia, 5, Lisboa, 1984. p. 95-108.

- "Nas origens da rota anteriana", Diário de Notícias, Caderno

2, Lisboa, 12 Maio 1991. p. 3.

- "Para a compreensão de Antero de Quental", Seara Nova, 1126-

-27, Lisboa, 1951. p. 533-535 e 547.

- "A procura filosófica de Antero", Seara Nova, 22, Mar.- Abr., Lisboa, 1989. p. 19-21.

- "Quental, Antero Tarquínio de", Dicionário de História de Portugal. Dir. por Joel Serrão. Porto, Livraria Figueirinhas, s.d. p. 213$-218$.

- "Sobre a filosofia de Antero", Atlântico, 19, Funchal, 1989. p. 
221-224.

- "Socialismo português radica em Antero", JL-Jornal de Letras, Artes e Ideias, Ano X, n 445, Lisboa, 15 Jan. 1991. p. 7.

- "Testamento Filosófico de Antero de Quental (Antologia)", Mundo Literário, 20, Lisboa, 1946. p. 10-11.

SESSA, Francisco - "Algumas líricas filosóficas de Antero de Quental. Trad. de José Tavares", Labor, 26(205), Aveiro, 1961. p. 3-15.

- "Líricas de inspiração amorosa de Antero de Quental", Labor, 218, Aveiro, 1963. p. 328-334.

SILVA, Agostinho da - "Consideração sobre o papel de Antero", Seara Nova, 406-408, Lisboa, 1934. p. 361-362.

SILVA, António Sérgio - "O império do espírito", Diário de Notícias, Caderno 2, Lisboa, 12 Maio 1991.p. 4.

SILVA, Fernando Manuel Soares - Antero de Quental: the existentialist poet-philosopher. His philosophy and educational thought. Lisboa, Atelier Gráfico Novotipo, 1969. 180 p.

- Antero de Quental. Evolução da sua filosofia existencialista e do seu pensamento pedagógico. Angra do Heroísmo, Direç̧ão dos Serviços de Emigração, 1986. 189 p.

- The philosophic and educational thought of Antero de Quental. Berkeley, University of California, 1968.

SILVA, Lúcio Craveiro da - Antero de Quental: evolução do seu pensamento filosófico. Braga, Livraria Cruz, 1959. 160 p.

- "Antero de Quental. O primeiro filósofo da encruzilhada", Revista Portuguesa de Filosofia, 16(2), Braga, 1960. p. 142-149. - "Evolução do pensamento filosófico de Antero de Quental", Brotéria, 24, Lisboa, 1937. p. 63-64, 152-162, 272-282, 527-544. - "O anterismo filosófico", Brotéria, 32, Lisboa, 1941. p. 59-66. - "O problema vital de Antero", Brotéria, 34 (4), Lisboa, 1942. p. 361-369.

- "O sentimento moral e religioso na filosofia de Antero", Revista Portuguesa de Filosofia, 47(2), Braga, 1991. p. 209-226.

SILVA, Natália - Pequeno estudo sobre a personalidade de Antero de Quental. s.l., s.n., s.d.

SILVA, Pereira da - "Antero pensador", Ágora, 1(1), Rio de Janeiro, 1935. p. 4-10.

SILVA JÚNIOR, J. - $O$ operário Antero. Ponta Delgada, Of. do 


\section{Elementos para uma bibliografia}

Diário dos Açores, 1942. $12 \mathrm{p}$.

SILVEIRA, Pedro - Antologia da poesia açoriana do séc. XVIII a 1975. Lisboa, Sá da Costa, 1977. 356 p.

SILVEIRA, Tasso - "Antero e Cruz e Souza", Atlântico. Revista Luso-Brasileira, 3, Lisboa/Rio de Janeiro, 1943. p. 42-45.

SIMÕES, João Gaspar - Antero de Quental. Lisboa, Ed. Presença, 1962. 262 p. il.

- Eça de Queirós. Lisboa, Arcádia, s.d.. 233 p.

- A Geração de 70. Alguns tópicos para a sua história. Lisboa, Ed. Inquérito, s.d.. $136 \mathrm{p}$.

SIMÕES, Manuel - "Antero inédito: os antecedentes do suicídio", Brotéria, 129(1), 1989. p. 43-51.

- "Antero inédito: o 'Programa da União Democrática'", Brotéria, 128(5-6), Lisboa, 1989. p. 483-493.

- "Novas cartas inéditas de Antero de Quental", Revista Portuguesa de Filosofia, 45(1), Braga, 1989. p. 3-19.

SIMÕES, Veiga - "Dissidência de Coimbra", in A nova geração. Coimbra, França Amado, 1911.p. 55-64.

SÓRIA, Andrés - "Antero de Quental", Diário 16 - Supl. Cultura, $\mathrm{n}^{\circ}$ 67, Madrid, 20 Jul. 1986. p. IV-V.

SOUSA, Antónia de - "Quem matou Antero?", Diário de Notícias, Supl. Cultura, Lisboa, 19 Nov. 1989. p. 7-8 e 34.

SOUSA, Clementino Moniz de - Antero e os seus amigos contemporâneos. Funchal, Ed. Eco do Funchal, 1958. 31 p.

SOUSA, Fernando Aires Medeiros - Faria e Maia e Antero. Subsídio dos Açores para a história da Filosofia. Coimbra, Ed. do Autor, 1960. 74 p. Tese de licenciatura policopiada.

- Faria e Maia e Antero. Angra do Heroísmo, s.n., 1961.

SOUSA, José Tomás de - O socialismo e Antero de Quental. Lisboa, Livraria Clássica Editora, 1942.80 p.

SOUSA, Nestor - "Mitografia de Antero", Açoriano Oriental, Ponta Delgada, Ano 157, n. ${ }^{\circ}$ 10348, 11 Jul. 1991. Supl. Pulsar. p. I, IV,V.

SOUSA, Ricarte-Dácio de - "A homenagem fadista", Diário de Notícias, Caderno 2: "Antero de Quental, O príncipe da agonia", Lisboa, 12 Maio 1991. p.12.

SPINELLI, Miguel - "Antero de Quental. Considerações sobre o seu filosofar", O Primeiro de Janeiro. Supl. "Das Artes, Das Letras", 
Lisboa, 9 Maio 1981. p. III.

- "Fundamentos filosóficos das Prosas de Antero de Quental", Revista Portuguesa de Filosofia, 43(1-2), Braga, 1987. p. 157-175. STORCK, Wilhelm - "Anthero de Quental (poema)", Nova Alvorada, Anno 1, n 7 , Vila Nova de Famalicão, 1 Nov. 1891. p. 62. - "O prefácio de. Wilhelm Storck à tradução alemã dos 'Sonetos' de Antero de Quental. Tad. Vírgínia Clara Vaz Pereira da Silva Pracana. Sep. de Insulana, nos 1 e 2, Vol. VII, 1951. 36 p.

SUPICO, Francisco Maria - "Antero de Quental", A Persuasão, Ponta Delgada, 16 Set. 1891.p. 1.

TEIXEIRA, António Braz - "Raízes krausistas do pensamento de Antero", Revista Portuguesa de Filosofia, 47(2), Braga, 1991. p. 255-264.

TEIXEIRA, Luís - "No centenário do poeta. Alguns factos da sua vida", Diário de Notícias, Lisboa, 18 Abr. 1942. p. 1 e 2.

- Vida de Antero de Quental. Lisboa, Livraria Clássica Editora, 1942. $86 \mathrm{p}$.

TELES, Basílio - "A Liga Patriótica do Norte", in Do Ultimatum ao 31 de Janeiro. Porto, Portugália, 1905. p. 121-133.

O Tiranete: Quental e Ortigão: Verso, com um retrato do autor. Porto, Livraria e Tipografia de F. G. da Fonseca, 1866. 16 p.

TORGAL, Luís Reis - "A recuperação de Antero pelo Estado Novo", Revista de História das Ideias, 13, Coimbra, 1991. p. 401-439.

TORRES, Flausino - Notas acerca da Geração de 70. Lisboa, Portugália Editora, 1967. 463 p.

TORREZÃO, Guiomar - "Antero de Quental", in As batalhas da vida. Lisboa, 1892. p.195-198.

TOSCANO, Alberto - Antereana. Partitura musical. Santa Maria da Feira, s.n., 1989. 59 p.

TRIGUEIROS, Luís Forjaz - "As cartas anterianas de Vila do Conde", O Primeiro de Janeiro. Supl. "Das Artes, Das Letras", Lisboa, 31 Mar. 1981.

VALENTE, A. L. dos Santos - "Uma carta inédita", in Anthero de Quental. In Memoriam. Porto, Mathieu Lugan, Ed., 1896. p. 111$-113$.

VASCONCELOS, Antão de - "Sociedade do Raio. Antero de Quental", in Memórias do Mata-Carochas. Porto, Empreza Litteraria e Typographica, Editora, s.d.. p. 211-218. 
VASCONCELOS, Carolina Michaëlis de - "Antheroe a Alemanha", in Anthero de Quental. In Memoriam. Porto, Mathieu Lugan, Ed., 1896. p. 385-425.

VASCONCELOS, Florido de - "Antero e Gomes Monteiro: história de um desentendimento", O Tripeiro, Série Nova, ano IX, $\mathrm{n}^{\circ} 11$, Porto, 1990. p. 338-342.

VASCONCELOS, Henrique de - "Dois poetas", in O festival de João de Deus. Lisboa, Antiga Casa Bertrand-Jose Bastos Editor, 1905. p. 146-147.

VASCONCELOS, J. Leite de - "Algumas particularidades da vida de Antero", in Mês de sonho. Lisboa, s.n., 1926. p. 203-204.

- "Carta autobiographica de Anthero de Quental", in $O$ doutor Storck e a literatura portuguesa. Lisboa, Academia das Ciências, 1910. p. 267-276.

- "Texto da tradução storckiana inedita de doze sonetos de Anthero de Quental", in $O$ doutor Storck e a literatura portuguesa, Lisboa, Academia das Ciências, 1910. p. 259-265.

VASCONCELOS, Joaquim - "Antero de Quental e a Liga Patriótica do Norte", A Revista, 9, Porto, 1904. p. 145-149.

- "Um avô do poeta: Bartholameu de Quental", in Anthero de Quental. In Memoriam. Porto, Mathieu Lugan, Ed., 1896. p. 523$-527$.

VASCONCELOS, Waldemar de - "Antero de Quental - O socialista e o amante da liberdade", Revista Americana de Letras, 40, Rio de Janeiro, 1942.

VAZ, Júlio N. - "A inquietação espiritual de Antero. Como explicar o fenómeno?", Via Latina, 11, Coimbra, 15 Maio 1942. p. 4-5.

VELOSO, A. - "O sinal 'menos' no pensamento de Antero", Brotéria, 49(1), Lisboa, 1949. p. 9-26.

VELOSO, Agostinho - Antero e os seus fantasmas. Ensaio filosófico do drama de Antero de Quental. Porto, Livraria Tavares Martins, 1950. $310 \mathrm{p}$.

- "Virtudes... enlouquecidas", Brotéria, 48(6), Lisboa, 1949. p. 678-689.

Os Vencidos da Vida: ciclo de conferências promovido pelo Círculo Eça de Queiroz. Lisboa, Círculo Eça de Queiroz, 1989. 165 p.

VICTOR, Jaime - "Anthero de Quental", Revista Illustrada, 35, Lisboa, 1891. p. 193-194. 
VIDAL, Eduardo Augusto - Guelfos e Gibelinos: tentativa crítica sobre a actual polémica literária. Lisboa, Livraria António Maria Pereira, 1866. $16 \mathrm{p}$.

VIEIRA, David J. - "El caballo negro en Antero de Quental y en Garcia Lorca y el tema amor-muerte", Thesaurus, 36 (1), Bogotá, 1981.p. 71-89.

VILA MOURA, Visconde de e CARNEIRO, António - "Antero de Quental", in Grandes de Portugal. Porto, Renascença Portuguesa, 1916. p. 27.

VILHENA, Henrique de - "A ascenção de Antero", Correio dos Açores, Ponta Delgada, 19 Abr. 1942. p. 1.

- "A evolução espiritual de Antero. Carta ao Dr. Joaquim de Carvalho, a propósito do seu estudo com êsse título", in Novos ensaios. Lisboa, Of. da Livraria Ferin, 1931. p. 247-282.

VITA, Luís Whashington - Antero de Quental. Tentativa de compreensão do sentido político de sua vida e sua obra. São Paulo, Departamento de Cultura, 1952.

VITA, Luís Washington - "Antero ou Proudhon?", Seara Nova, 1319-1320, Lisboa, 1956. p. 66-67.

- Antero de Quental. Rio de Janeiro, Departamento da Imprensa Nacional, 1961. 119 p.

- "Reflexões sobre Antero de Quental e a poesia revolucionária", Revista Brasileira de Filosofia, São Paulo, 2(3),1952. p. 523-530.

VITERBO, Sousa - "Anthero de Quental e o soneto camoniano", Nova Alvorada, Anno 1, nº 7, Vila Nova de Famalicão, 1 Nov. 1891. p. 75-76.

WALDRON, Terence P.-Os Sonetos de Antero de Quental. Trad. do inglês de João H. Anglin. Ponta Delgada, Tip. do Diário dos Açores, 1949. 23 p.

XAVIER, Alberto - "História do 'Manifesto dos estudantes de Coimbra à opinião ilustrada do país'", in História da greve académica de 1907. Coimbra, Coimbra Editora, 1962. p. 33-59

ZÚÑIGA, Juan Eduardo - "Antero de Quental", História 16, Ano XVI, no 183, Julho 1991. p. 112-120.

- "Recuerdo de Antero de Quental", Diário 16. Supl. Cultura, no 314, Madrid, 7 Set. 1991. p. IV.

- "Actualidad de Antero de Quental" El País, Supl. "Babelia, Revista de Cultura", Madrid, 16 Maio 1992. p. (22). 